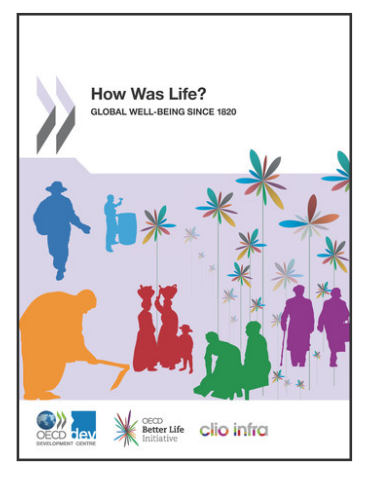

\title{
From:
}

How Was Life?

Global Well-being since 1820

Access the complete publication at:

http://dx.doi.org/10.1787/9789264214262-en

\section{Gender inequality since 1820}

\author{
Sarah Carmichael, Selin Dili, Auke Rijpma
}

Please cite this chapter as:

Carmichael, Sarah, Selin Dili and Auke Rijpma (2014), "Gender inequality since 1820", in Jan Luiten van Zanden, et al. (eds.), How Was Life?: Global Well-being since 1820, OECD Publishing. 
This work is published on the responsibility of the Secretary-General of the OECD. The opinions expressed and arguments employed herein do not necessarily reflect the official views of the OECD member countries, or those of the IISH.

This document and any map included herein are without prejudice to the status of or sovereignty over any territory, to the delimitation of international frontiers and boundaries and to the name of any territory, city or area. 


\section{Chapter 12}

\section{Gender inequality since 1820}

by

Sarah Carmichael, Selin Dilli and Auke Rijpma, Utrecht University

Historically, gender inequalities in health status, socio-economic standing and political rights have been large. This chapter documents gender differences in life expectancy and birth rates (to cover health status); in average years of schooling, labour force participation, inheritance rights and marriage age (to cover socioeconomic status); and in parliamentary seats and suffrage (to cover political rights). A composite indicator shows strong progress in reducing gender inequality in the past 60 years in most regions. Only in East Asia and in Eastern Europe this decline stalled in the 1980s. Differences in levels of gender inequality between regions remained large, however: Europe (including Eastern Europe) and the Western Offshoots performed best, although no country reached full gender equality. The Middle East and North Africa (mainly due to weak political rights) and South and Southeast Asia (due to skewed sex ratios at birth) performed worst. 


\section{Introduction}

The previous chapters of this volume have given an overview of how the world's population has fared over the past 190 years, with the focus being either on the general population or on men (i.e. the real wages chapter, for which female data is unavailable). Women make up roughly $50 \%$ of the world's population. However when it comes to equality between men and women, the world remains an unequal playing field (Duflo, 2012). Given this, any view of global well-being is incomplete without taking into consideration inequalities between men and women. For example, property rights favouring male ownership persist throughout the developing world (Weldon and Htun, 2012). Furthermore, male-biased sex ratios, usually interpreted as a sign of mistreatment of women and above all female infants, remain in evidence, or have become more pronounced, particularly in Asian countries such as China (Klasen and Wink, 2003). In economically developed countries gender inequality persists in the form of gender pay differences, whereby women who are equally qualified continue to earn less than men at all levels of qualification (e.g. Arulampalam et al., 2007). Even in highly democratic countries women continue to be under-represented in the political sphere. As of July 2013, the proportion of seats held by women in single or lower houses of parliament was only $21.3 \%$ globally and only $22.7 \%$ in European countries (Inter-Parliamentary Union, 2011).

These gaps between the sexes are not just important from an intrinsic, social justice perspective, but also from an instrumental one. The results of a number of studies have shown the importance of women for a wide range of development outcomes, and because of this the international community has come to the conclusion that addressing gender equality is an important part of any development initiative. ${ }^{1}$ Improving women's rights in terms of access to resources and legal standing has been shown to improve, amongst other things, children's educational attainment (Currie and Moretti, 2003; King et al., 1986; Schultz, 1988), agricultural productivity (FAO, 2011), economic growth (Klasen, 2002; Klasen and Lamanna, 2009) and the quality of government, particularly by reducing corruption (Dollar, Fishman and Gatti, 2001). ${ }^{2}$ Striving for gender equality therefore appears to be a key driver in achieving many other development goals and to have effects across the board on various aspects of well-being for both men and women. ${ }^{3}$

Gender relations and roles are not phenomena that change overnight. Rather, gender inequality has historical roots. One author who demonstrates this is Katherine Lynch (2011). She concludes that the fact that Western Europe has not seen noticeable levels of "missing women" since the 16th century can be ascribed to family structures, opportunities for paid labour and elements of Christianity that had long been present. This stands in sharp contrast to both the historical and the present-day experience of countries such as India and China. Another example is that of the Western European marriage pattern, which emerged in the late Middle Ages, and was characterised by a shift from parental to individual consent to marriage decisions. The key characteristic of this European marriage pattern was that women had an equal say in the marriage decision and were involved 
in the household decision-making process on an equal footing with their husbands (Van Zanden and De Moor, 2010).

Although gender inequality is a persistent trait of many countries, there are also important differences between countries and regions of the world. A long-term perspective is essential to understanding gender inequality within and between countries. In addition to allowing us to understand where and how gender inequalities emerge and persist, a long-term perspective should also allow better exploration of the relationship between gender inequality and economic development (Lagerlöf, 2003).

In order to better understand gender equality and its relationship to the development process, it is thus necessary to find ways to measure gender relations over time. This chapter therefore seeks to address three interrelated questions. First, how can we measure gender inequality in a historical perspective and, second, using these measures, what trends do we observe in gender equality in the world economy over the last 200 years? Lastly, we also want to explore the question, to what extent does a relationship exist between gender equality and economic development in the long run? These questions are addressed by analysing a wide range of indicators of gender equality in the 20th century, based upon indicators used in currently available gender equality indices.

Even though the empowerment of women and closing the gap between the two genders have been widely acknowledged as important development objectives, for the reasons sketched above, finding "methods for systematically measuring and tracking changes in levels of gender equality" is not straightforward (Malhotra, 2003). There have been numerous efforts by researchers and international bodies to develop accurate measures of gender equality. The UNDP's Gender-related Development Index (GDI) and its replacement, the Gender Inequality Index (GII), are perhaps the best-known examples. ${ }^{4}$ Most of these measures have aspects and variables in common, though some focus more on gender inequalities in outcomes (such as gender disparities in human capital), and some focus more on the social institutions underlying gender inequality. One example of an index that focuses on the institutions underlying gender inequality is the Social Institutions and Gender Index (SIGI) compiled by the OECD's Development Centre (Branisa et al., 2009). This index looks at a wide range of institutional measures that capture different aspects of gender inequality, such as whether women have the same rights of legal guardianship of their children during marriage, women's legal protection from rape, and women's legal access to land.

The fact that women have started to be placed more prominently on the development agenda has resulted in different conceptualisations and measurements of women's empowerment. However, despite this proliferation of conceptualisations and measures, most studies are limited to the contemporary time period. None of the available indices start before 1995, meaning we lack a long-term perspective, which is crucial for understanding progress towards gender equality. For instance, these indices would miss the gains made by women in terms of life expectancy in the period since the 1950s, as everywhere in the world women now live longer than men. ${ }^{5}$ Similarly, one can see the impact of China's one-child policy on missing girls only if the evolution of sex ratios are also analysed for the period before 1980 (World Bank, 2011). Lastly, such a long-term perspective not only provides an overview of changes in gender inequalities, but also helps in comparing the experience of different countries in the long run. Some inequalities can be pinned on the level of economic development, while others are more institutional in nature, something that becomes apparent when comparing historical gender inequality across the spectrum of institutional and developmental variety in the historical record. 
In sum, the causes of gender equality and the prospects for improvement can be understood only by means of long-term, comparative analysis. This chapter aims to take a first step towards that goal. Though constrained by issues of data availability, we build on the ideas of the various gender indices available to choose variables that capture various aspects of gender inequality over time.

\section{Description of the concepts used}

Gender inequality manifests itself in many dimensions of daily life (from domestic violence in the household to unequal wage practices in the workplace, etc.) and results in unequal opportunities for participation in political and economic decision-making for men versus women (OECD, 2013). This chapter provides an overview of gender inequalities in various dimensions of well-being, following the conceptual framework of How Is Life? (OECD, 2013) and the current study on A Long-Term Perspective on Global Well-being and Development (OECD, 2014), whenever that data is available by gender. Furthermore, discrimination can take place throughout a woman's life cycle, from birth (resulting from sex-selective abortions, such as in the case of China) to access to education (for instance in school enrolment rates) and continuing through the rest of their life course (e.g. labour force participation and life expectancy) (OECD, 2013). For this reason, a range of indicators are selected that capture gender inequality at different stages of the life cycle. Lastly, the chapter focuses on the indicators that have been shown to matter for the overall development of the societies (e.g. World Bank, 2011).

In choosing indicators of gender inequality, the analysis in this chapter is constrained by the availability of historical data. For this reason, not all key issues that affect women's well-being and are included in contemporary gender inequality indices could be covered. It was not possible, for instance, to include measures such as income or access to highpaying jobs, which are crucial factors for the economic standing of women (Kabeer, 1999) 6 What is lost in comparability with present-day indices, however, is made up for in the long-term perspective 7 Despite constraints in data availability, there are theoretical and methodological criteria behind the choice of the gender equality variables employed. First, the focus is on internationally comparable measures since the aim is to produce a global picture of gender inequality 8 second, the chapter gives an indication of gender disparities that result from institutional, cultural and social influences (OECD, 2013). Branisa et al. (2013), for example, attribute cross-national differences in female schooling largely to the institutional structures affecting gender equality, in particular whether women can inherit. Another institutional indicator related to gender equality for which data is available is suffrage. The extension of voting rights to women is not only important for the intrinsic reason that it promotes equality of opportunities between the two genders, but also because it is associated with increases in the extent of social spending, particularly on education and health (see Lindert, 2004, for evidence on the United States in the early 20th century). Third, the chapter focuses on measures that are available over long time periods, as the intent is to capture the progress that countries have made towards gender equality. However, fertility, which is a commonly used measure in composite gender equality measures (see, for example, the UNDP's Gender Inequality Index), is excluded as it provides only an indirect indication of women's position. In doing this, the chapter follows, amongst others, Donno and Russet (2004: 588) who argue that although low fertility may be indicative of the degree of female reproductive rights, it may also "reflect coercive population policies enforced on women". 
Gender disparities are analysed along four dimensions that are commonly discussed in the literature. First, there is the very basic issue of women's health. For example, women's very existence may be threatened by sex-selective abortions and neglect in medical care. More generally, whether women have the same opportunities as men to live a long and healthy life is of fundamental importance to equality and well-being. Second, the chapter looks at socio-economic standing. Whether or not women are able to be economically independent not only has intrinsic importance, but can also have indirect effects on women's position in the household by strengthening their options beyond marriage and childbearing (Gray, 1998; Sen, 1990). The position of women in terms of socio-economic resources affects not only their own well-being but also that of their offspring. Generally speaking, the household (with special reference to the married couple at the head of the household) is where many important decisions relating to women's position are made (Klasen, 1998, p. 437). For this reason, the third field considered is the marital position of women. Fourth, in most countries, men have more influence in political decision-making processes because they are overrepresented in public office. This is therefore an arena where there is much to be gained in terms of gender equality.

In line with the Global Gender Gap Index, while presenting different dimensions of gender inequality we focus on gender gaps in development outcomes in individual countries rather than the actual levels of resources and opportunities available to women. This is so as to evaluate the gender differences independent of a country's level of development. However, a discussion of how women are performing in absolute terms is included when relevant, as it is important to understand whether gender gaps are closing over time due to improvements in women's position or the worsening of men's position (in the case of life expectancy in parts of Eastern Europe, for example).

The aim here is to capture the multidimensional nature of gender equality and at the same time to obtain a general view of countries' performances when gender disparities in outcomes are evaluated together. The chapter therefore includes a historical composite measure of gender equality, which takes its inspiration from the composite gender equality indices offered by the United Nations (the Gender Inequality Index) and the World Economic Forum (the Global Gender Gap Index). This composite measure focuses on gender disparities in societal outcomes related to the four dimensions described above, and excludes institutional measures such as inheritance practices 9 More detailed information on the theoretical background and the construction of the historical gender equality index can be found in Dilli et al. (2014a).

\section{Historical sources}

This section describes the data sources for the variables capturing different dimensions of gender inequality. Most of the measures go back to the beginning of the 20th century. The exceptions are the data on education and labour force participation, which are available from 1950 onwards. Table 12.1 presents an overview of the variables used in this chapter or in the composite index, along with their source and summary statistics.

Before turning to the variables for which there is annual data, first an overview is given of gender differences in institutional structure that can be compared globally throughout the 20th century. To start with, global patterns of inheritance practices are examined. These indicate the extent to which women could inherit and are available at three time points; 1920, 1980 and 2000. Information on inheritance practices at the start of the 20th century 
Table 12.1. Gender equality indicators, coverage and summary statistics

\begin{tabular}{llccccl}
\hline Dimension & \multicolumn{1}{c}{ Indicator } & Range & Mean $(\mathrm{sd})$ & Countries & Years & Source \\
\hline Health & Life expectancy ratio & $0.87-1.66$ & $1.08(0.05)$ & 130 & $1900-2003$ & $\begin{array}{l}\text { UN (2013); lifetable.de, Human Mortality } \\
\text { Database; Preston (1975) }\end{array}$ \\
& Sex ratio & $0.83-1.23$ & $0.97(0.02)$ & 130 & $1900-2003$ & Mitchell (2007); UN (2013) \\
$\begin{array}{l}\text { Socio-economic } \\
\text { standing }\end{array}$ & $\begin{array}{l}\text { Average years schooling } \\
\text { ratio }\end{array}$ & $0.03-1.46$ & $0.73(0.26)$ & 130 & $1950-2000$ & Barro and Lee (2013) \\
& $\begin{array}{l}\text { Labour force participation } \\
\text { ratio }\end{array}$ & $0.02-1.29$ & $0.6(0.24)$ & 130 & $1945-2003$ & ILO (2010) \\
& Inheritance & $0-1$ & $0.56(0.50)$ & 159 & $1920-2000$ & Murdock (1976); Hallward-Driemeier et al. (2013) \\
Household & Marriage age ratio & $0.61-0.98$ & $0.85(0.07)$ & 129 & $1900-2003$ & Carmichael (2013) \\
Political & Parliament seats ratio & $0-0.95$ & $0.06(0.10)$ & 130 & $1900-2003$ & Paxton et al. (2008), online electoral archives \\
& Suffrage & $0-1$ & $0.35(0.48)$ & 152 & $1900-2000$ & Paxton et al. (2008); Przeworski (2009) \\
\hline
\end{tabular}

Note: For an assessment of data quality, see Table 12.2.

comes from George Murdock's Ethnographic Atlas (1969), updated and turned into countrylevel variables by Jutta Bolt (2012). Murdock's Atlas includes information on 1267 societies for the period 1850-1950. It provides information on the gender distribution of inheritance of land and inheritance of movable property. Both are split into 8 possible classifications: missing data, absence of individual property rights, matrilineal (sisters' sons), other matrilineal (i.e. youngest brothers), children with daughters receiving less, children equally, other patrilineal, and patrilineal (sons). To compare these to contemporary data available from the World Bank's Fifty Years of Women's Legal Rights database, a dichotomous scheme had to be used where 0 indicates inequality and 1 equality. Next, data from the World Bank's legal rights database for the years 1980 and 2000 is used to show changes over time in gendered inheritance practices.

As a second measure of the institutional environment related to gender equality, data on the year women were granted the right to vote in national elections is employed. This data gives the year when legislation was introduced that allowed women to vote for the first time, even if they were granted this right on a narrower basis than men. The data comes from Paxton et al. (2008). Based on this information, a dummy variable was created where a score of 1 was given for the years where women have the right to vote. This information is then mapped for 1913, 1950 and 2000 to give an idea of changes in female suffrage over the past century. In order to have a better overview of gender inequalities related to suffrage, data on male suffrage has been gathered from Przeworski (2009). This can be used to compare the gap in years between when men and women respectively got the vote. ${ }^{10}$

To evaluate the ability of women to live a long (and healthy) life, the chapter first turns to gender differences in life expectancy. As discussed in Chapter 6 of this volume on Life Expectancy, UNWPP (United Nations World Population Prospects) data is used for the post-1950 period and Clio-infra data and various data sources for the earlier period (see Table 12.1). The ratio of men's life expectancy to women's is then calculated.

Next, to further capture the health dimension, Sen's (1992) concept of missing women is used. The ratio of women to men for the age category between 0 and 5 is calculated. The focus is on this age category rather than later stages of life for two reasons. The first is that three-fifths of missing women go missing during birth and infancy/childhood. 
Second, missing girls at birth reflects discrimination in the household, resulting from the combination of strong preferences for sons combined with declining fertility and the spread of technologies that allow parents to learn the sex of the child before birth. Missing girls/women at later stages of the life cycle reflect not only discriminatory practices against women, but also poor institutions, such as lack of healthcare or water and sanitation infrastructure (World Bank, 2011). Thus, the measure used here specifically focuses on a sex-selection bias in the period of early infancy, where the bias is caused by abortion, infanticide, and the possibility that young girls are systematically less cared for in early childhood (Anderson and Ray, 2010). The data comes from Mitchell (2007) and the UN (2013).

As an indication of the gender differences in marriage patterns, the ratio of female Singulate Mean Age at Marriage (SMAM) to male SMAM is taken. The data comes from Carmichael (2011), and is based on various resources, amongst which statistics from the United Nations, World Bank, Demographic Healthy Surveys, Hajnal (1965), Van Zanden and De Moor (2009) and national censuses. The SMAM statistic was developed by Hajnal (1965) and is a calculation of the average length of single life expressed in years among those who marry before age 50 (United Nations, 2008). On average men marry younger women; however, where the age gap between spouses is low it is more likely that the partnership will be an equal, companionate one. A large difference in marriage ages is therefore likely to reflect an unequal position of spouses, and even arranged and child marriages (Caldwell, Reddy and Caldwell, 1983).

Differences in the socio-economic position of men and women are highlighted by looking at educational attainment. This data comes from Barro and Lee (2010), as their dataset - to the best of our knowledge - has the highest level of global coverage on human capital by gender. ${ }^{11}$ Data on average years of schooling for the male and female population aged over 25 is employed. ${ }^{12}$ To highlight the educational differences between men and women, the ratio of women's to men's average years of schooling is used.

To capture the political position of women, the percentage of women in parliaments is used as an indicator. The data on the percentage of women in parliament comes largely from the Women in Parliament 1945-2003 dataset (Paxton et al., 2008). This data was extended back until the beginning of the 20th century in 1907 when the first woman MP was elected in Finland. Supplementary data was collected on all the countries that had women in parliament for the time period between 1907 and 1945 from various online electoral archives. Using the data on the percentage of women in parliament, the equivalent male value can easily be derived, and these two results were expressed as a ratio of women to men.

As mentioned earlier, it is also of interest to consider how these different dimensions of gender inequality come together and develop. This is done by employing the composite index of gender equality created by Dilli et al. (2014a, 2014b), which has been constructed by using the variables described above (excluding the institutional indicators) and which is available from 1950 onwards. ${ }^{13}$ The historical gender equality index is a continuous measure ranging between 0 and 100 where a score of 100 represents equality between the genders.

\section{Data quality}

Issues of comparability and data limitations are unavoidable in creating and compiling a series of historical measure on gender equality on a global scale. So while this study does provide an overview of how gender inequality has changed since the early 20th century, it does have limitations (Table 12.2). First of all, although trends in a number of indictors from 
the late 19th century onwards can be described, data coverage improves significantly from 1950 onwards. The geographic coverage is also a challenge, since historical data on gender equality is scarce for countries outside of Western Europe and a handful of other large countries. Furthermore, only an overview can be given for institutions related to gender equality in terms of inheritance and voting rights. It is, therefore, not possible to capture many other aspects that matter for gender equality, such as violence against women or freedom of movement, as the OECD (Branisa et al., 2009) does for the SIGI. Furthermore, it is not possible to provide a full overview of the economic well-being of women, as historical data on indicators such as female labour force participation and female wages are scarce or not systematically available on a cross-national scale 14 It is also not possible to capture the unequal allocation of time use in the home, which is closely related to the well-being of women outside the household, linked as it is to political participation and labour force participation (Verba et al., 1997).

Another issue that has to be acknowledged here is that the size of the gender disparities in various dimensions described above is likely to differ between groups within countries, depending on socio-demographic and economic status (e.g. age group, health status, country of origin, income, urban-rural). However, although a within-country comparison on gender equality between different socio-economic groups might shed further light on the causes for and mechanisms perpetuating gender inequality, the point of this study is to analyse such trends at the macro level. Individual or group level analysis is beyond the scope here, and so it is left to others to take up this gauntlet in future research.

A further concern that should be noted is the comparability of these measures in a cross-national setting, which requires cautious use of the data. For instance, for the marriage indicator, a comparison can be made only based on legally documented marriages. Definitions of marriage differ in different contexts, muddying the data somewhat. Similar issues occur when one wants to measure women's political participation. The only comparable data on a global scale are on the date of suffrage and the percentage of female seats in parliament, which provide a very limited overview of gender disparities in politics. Because data on conventional forms of political participation (such as voting trends) are not available due to secret ballot systems, and as a result of the difficulty of capturing unconventional forms of political participation, such as protesting, with quantitative methods, it is very difficult to measure other forms of women's political participation. A similar issue arises when using data on education. Although the chapter reflects on the overall performance in terms of closing the gender gap in average years of education, this measure hides any gender imbalances related to the choice of academic field (e.g. young women being less likely than young men to choose Science, Technology, Engineering, or Mathematics (STEM) subjects as a field of study at the tertiary level), which later in life translates into occupational segregation (OECD, 2013). Furthermore, to achieve the greatest coverage in terms of time period, different data sources had to be employed, which sometimes come at the cost of jumps in the estimates.

When available, the quality of the data is typically quite high. Most observations are estimates of official statistical agencies (1) or the product of historical research using the same sources and methods as these agencies (2). The quality of the data for sex ratios is similar to that of most other indicators used in this chapter. The only exception is the data on marriage ages. Here, the estimates for the period up to 1870 are usually based on the same kind of data and method as statistical agencies would use, but do not always cover the entire country. 
Table 12.2. Quality of data on ratios of boys to girls, parliamentary seats ratio, and marriage age ratio by region and benchmark year, 1820-2008

\begin{tabular}{|c|c|c|c|c|c|c|c|c|}
\hline \multicolumn{9}{|c|}{ Sex ratios } \\
\hline & $\begin{array}{c}\text { Western } \\
\text { Europe } \\
\text { (WE) }\end{array}$ & $\begin{array}{c}\text { Eastern } \\
\text { Europe } \\
\text { (EE) }\end{array}$ & $\begin{array}{c}\text { Western } \\
\text { Offshoots } \\
\text { (W0) }\end{array}$ & $\begin{array}{c}\text { Latin } \\
\text { America } \\
\text { and } \\
\text { Caribbean } \\
\text { (LA) }\end{array}$ & $\begin{array}{c}\text { Sub-Saharan } \\
\text { Africa } \\
\text { (SSA) }\end{array}$ & $\begin{array}{l}\text { Middle East } \\
\text { and } \\
\text { North Africa } \\
\text { (MENA) }\end{array}$ & $\begin{array}{c}\text { East Asia } \\
\text { (EA) }\end{array}$ & $\begin{array}{c}\text { South and } \\
\text { South-East } \\
\text { Asia } \\
\text { (SSEA) }\end{array}$ \\
\hline 1820 & 2 & 2 & 2 & 2 & 2 & 2 & 2 & 2 \\
\hline 1870 & 2 & 2 & 2 & 2 & 2 & 2 & 2 & 2 \\
\hline 1913 & 2 & 2 & 2 & 2 & 2 & 2 & 2 & 2 \\
\hline 1950 & 1 & 1 & 1 & 1 & 1 & 1 & 1 & 1 \\
\hline 1973 & 1 & 1 & 1 & 1 & 1 & 1 & 1 & 1 \\
\hline 2008 & 1 & 1 & 1 & 1 & 1 & 1 & 1 & 1 \\
\hline \multicolumn{9}{|c|}{ Parliament ratios } \\
\hline & $\begin{array}{c}\text { Western } \\
\text { Europe } \\
\text { (WE) }\end{array}$ & $\begin{array}{c}\text { Eastern } \\
\text { Europe } \\
(\mathrm{EE})\end{array}$ & $\begin{array}{c}\text { Western } \\
\text { Offshoots } \\
\text { (WO) }\end{array}$ & $\begin{array}{l}\text { Latin } \\
\text { America } \\
\text { and } \\
\text { Caribbean } \\
(\mathrm{LA})\end{array}$ & $\begin{array}{c}\text { Sub-Saharan } \\
\text { Africa } \\
\text { (SSA) }\end{array}$ & $\begin{array}{l}\text { Middle East } \\
\text { and } \\
\text { North Africa } \\
\text { (MENA) }\end{array}$ & $\begin{array}{l}\text { East Asia } \\
\text { (EA) }\end{array}$ & $\begin{array}{c}\text { South and } \\
\text { South-East } \\
\text { Asia } \\
\text { (SSEA) }\end{array}$ \\
\hline 1820 & 1 & 1 & 1 & 1 & 1 & 1 & 1 & 1 \\
\hline 1870 & 1 & 1 & 1 & 1 & 1 & 1 & 1 & 1 \\
\hline 1913 & 1 & 1 & 1 & 1 & 1 & 1 & 1 & 1 \\
\hline 1950 & 2 & 2 & 2 & 2 & 2 & 2 & 2 & 2 \\
\hline 1973 & 2 & 2 & 2 & 2 & 2 & 2 & 2 & 2 \\
\hline 2008 & 2 & 2 & 2 & 2 & 2 & 2 & 2 & 2 \\
\hline \multicolumn{9}{|c|}{ Marriage ratios } \\
\hline & $\begin{array}{c}\text { Western } \\
\text { Europe } \\
\text { (WE) }\end{array}$ & $\begin{array}{c}\text { Eastern } \\
\text { Europe } \\
\text { (EE) }\end{array}$ & $\begin{array}{c}\text { Western } \\
\text { Offshoots } \\
\text { (WO) }\end{array}$ & $\begin{array}{l}\text { Latin } \\
\text { America } \\
\text { and } \\
\text { Caribbean } \\
\text { (LA) }\end{array}$ & $\begin{array}{c}\text { Sub-Saharan } \\
\text { Africa } \\
\text { (SSA) }\end{array}$ & $\begin{array}{l}\text { Middle East } \\
\text { and } \\
\text { North Africa } \\
\text { (MENA) }\end{array}$ & $\begin{array}{c}\text { East Asia } \\
\text { (EA) }\end{array}$ & $\begin{array}{c}\text { South and } \\
\text { South-East } \\
\text { Asia } \\
\text { (SSEA) }\end{array}$ \\
\hline 1820 & 3 & 3 & 3 & .. & .. & .. & .. & .. \\
\hline 1870 & 2 & 3 & 2 & .. & .. & .. &.. & .. \\
\hline 1913 & 2 & 2 & 2 & 2 & .. & .. & .. & 2 \\
\hline 1950 & 1 & 1 & 1 & 1 & 1 & 1 & 1 & 1 \\
\hline 1973 & 1 & 1 & 1 & 1 & 1 & 1 & 1 & 1 \\
\hline 2008 & 1 & 1 & 1 & 1 & 1 & 1 & 1 & 1 \\
\hline
\end{tabular}

Note: 1. High quality; 2. Moderate quality; 3. Low quality; and 4. Estimates. See the section on "Data Quality" in Chapter 1 for a description of the quality criteria.

Source: Clio-Infra, www.clio-infra.eu.

\section{Main highlights of trends in gender inequality}

This section presents trends in gender equality, first for the individual variables, and then the composite index. First, however, to give an idea of how the position of both women and men has improved in absolute terms over the past 100 years, statistics on average women and men in the 1900s, 1950s and 2000s are provided in Figure 12.1. These estimates are population-weighted averages covering at least $40 \%$ of the world's population, where missing countries are imputed to alleviate a bias against developing countries for which less statistical material is available.

In 1900, the average woman got married shortly before her 18th birthday to a man almost five years older than herself. Based on her life expectancy at birth, she could expect to be married for 18 years seeing as average life expectancy at birth was 35.5 years (though 


\section{Figure 12.1. Average life expectancy at birth, marriage age and average} years of education for women and men in the 20th century

Values in years

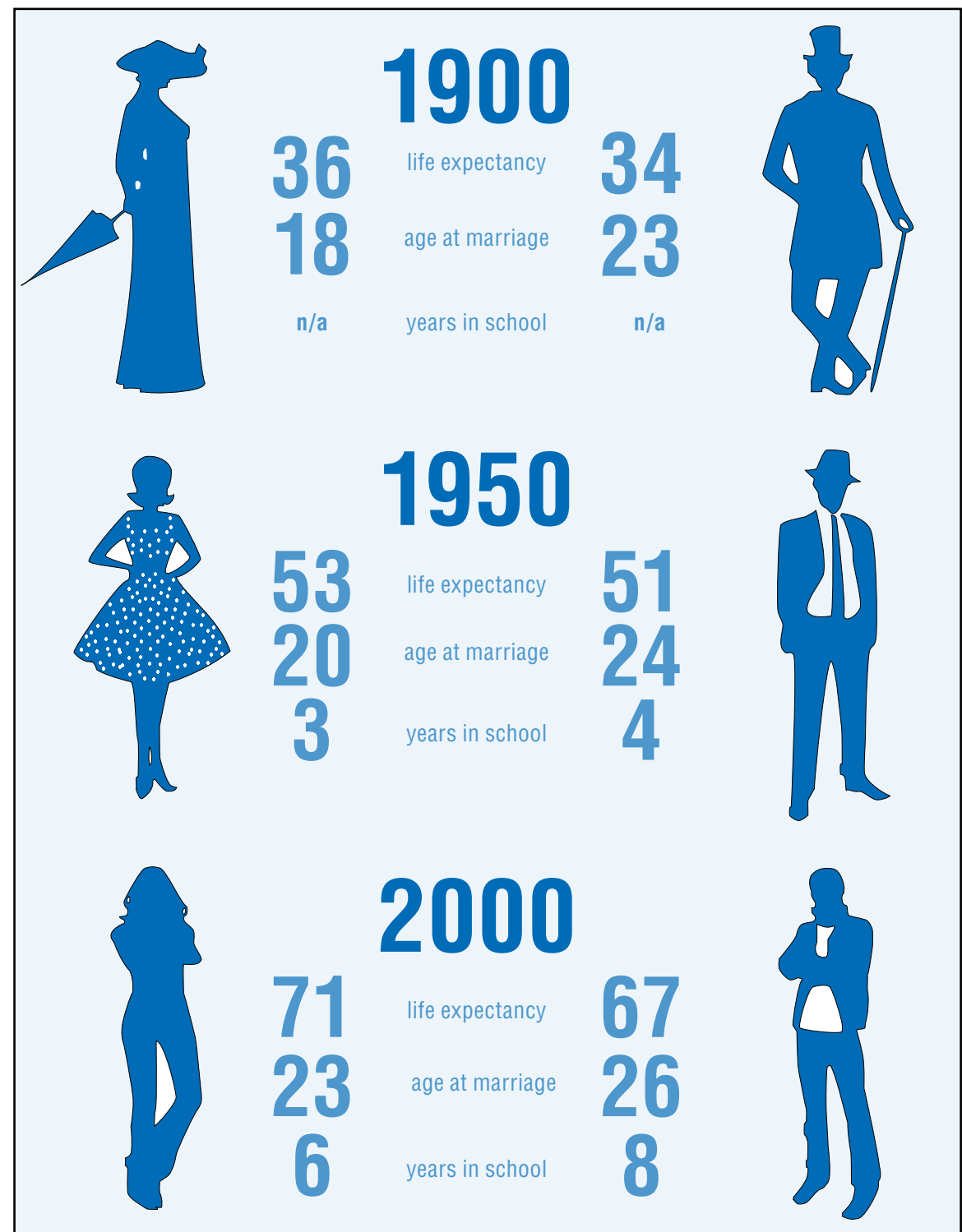

Note: For an assessment of data quality, see Table 12.2.

Source: Clio-Infra, www.clio-infra.eu.

StatLink ails $h t t p: / / d x . d o i . o r g / 10.1787 / 888933096255$

in actual fact she could be expected to be married for far longer, as life expectancy at age 18 will have been higher than that at birth). By the 1950s, however, she could expect to live 12 years longer and would marry just before her 20th birthday. Her educational attainment would be under 3 years compared to her husband's average educational attainment of just under 4 . As the benchmark for functional literacy is set in a range between 3 to 5 years of education (UNESCO has adopted the 5-year benchmark in its surveys on this issue), this means the average woman at this time would have limited literacy (Gray, 1969). Fifty years later the equivalent woman would have more than double the educational attainment of her 1950s sister, having spent on average almost 6.5 years in school. At birth she could expect to live 18 years longer than she would have in the 1950s, to halfway through her 
71st year. All in all, compared to her equivalent a century earlier, the average woman in the 2000s could expect to live nearly twice as long, marry almost six years later and be literate, thanks to 6.4 years of education attainment.

The average man's situation also improved over the course of the 20th century, but he made smaller gains in life expectancy, moving from not seeing his 35th birthday in the 1900 s to surpassing his 67 th in the 2000s. His level of education more than doubled from 3.64 years in the 1950s (just shy of functional literacy) to 7.64 years in the 2000s.

Moving from the abstract notion of the average male and female performance over the 20th century to the institutional environment in which they functioned, two measures of institutional inequality (which are not included in the composite measure), inheritance and voting rights, are presented in Figures 12.2 and 12.3. These measures give an idea of how the institutional/legislative environment is biased against women and thus of women's legal standing historically. The three panels presented in Figure 12.2 show gendered inheritance practices for immovables in 1920 (from the Murdock data), 1980 and 2000 (from the World Bank).

It becomes clear from the first map that gender equal inheritance systems were far from the norm in the early 20th century. Inheritance systems where daughters receive equal shares can be observed in some European countries, Brazil (likely because of the tradition of female inheritance in Portugal) and in a handful of countries in Southern Africa and Southeast Asia 15 By the 1980s substantial changes have taken place. A number of African, Eastern European, Central Asian and South American countries have shifted their legislation to require gender equal inheritance (possibly linked to the adoption of the Convention on the Elimination of Discrimination Against Women, CEDAW, by the UN General Assembly in 1979). Meanwhile, the countries that had gender egalitarian inheritance laws in the early 20th century have generally maintained them. Indonesia is an interesting exception to this rule. This is likely due to the Islamisation of Indonesian law following independence (Cammack and Feener, 2012; Lukito, 2013; and Salim, 2008). By 2000 , it can be observed that the majority of the world's countries for which there is data had equal inheritance rights, although the Middle East and North Africa (MENA) region remains as a belt of unequal rights.

Turning now to a different dimension of institutional arrangements, namely suffrage, the next three maps shown in Figure 12.3 present the geographical distribution of countries where women had the right to vote in 1913, 1950 and 2000.

It becomes clear from Figure 12.3 that the world has come a long way in providing equal rights to women in politics. In 1913, only New Zealand, Australia, Finland and Norway had granted women the vote. Among these countries, in 1893 New Zealand became the first to extend the franchise to women. The 1950 map makes clear that the interim period has seen a substantial extension of suffrage to women, as countries where women have the vote now outnumber those where only men could vote. Figure 12.4 below shows that the two big jumps in extending the vote to women came after the First and Second World Wars. Regional disparities are also present. All the countries in Western Europe and its Offshoots, except Switzerland, had granted women the right to vote by 1950, whereas this right was denied in most of the countries in the MENA and Sub-Saharan Africa. At the turn of the century, Qatar, Kuwait and Saudi Arabia were the only countries still denying this right to women. However, in 2011 Saudi Arabia, the last country in the world to deny this right, granted women the vote for the next elections, which will take place in 2015. 122 years after the first country granted women the vote, gender equality in this measure across the globe will have been achieved. 
Figure 12.2. Countries with gender-equal inheritance, 1920, 1980, 2000

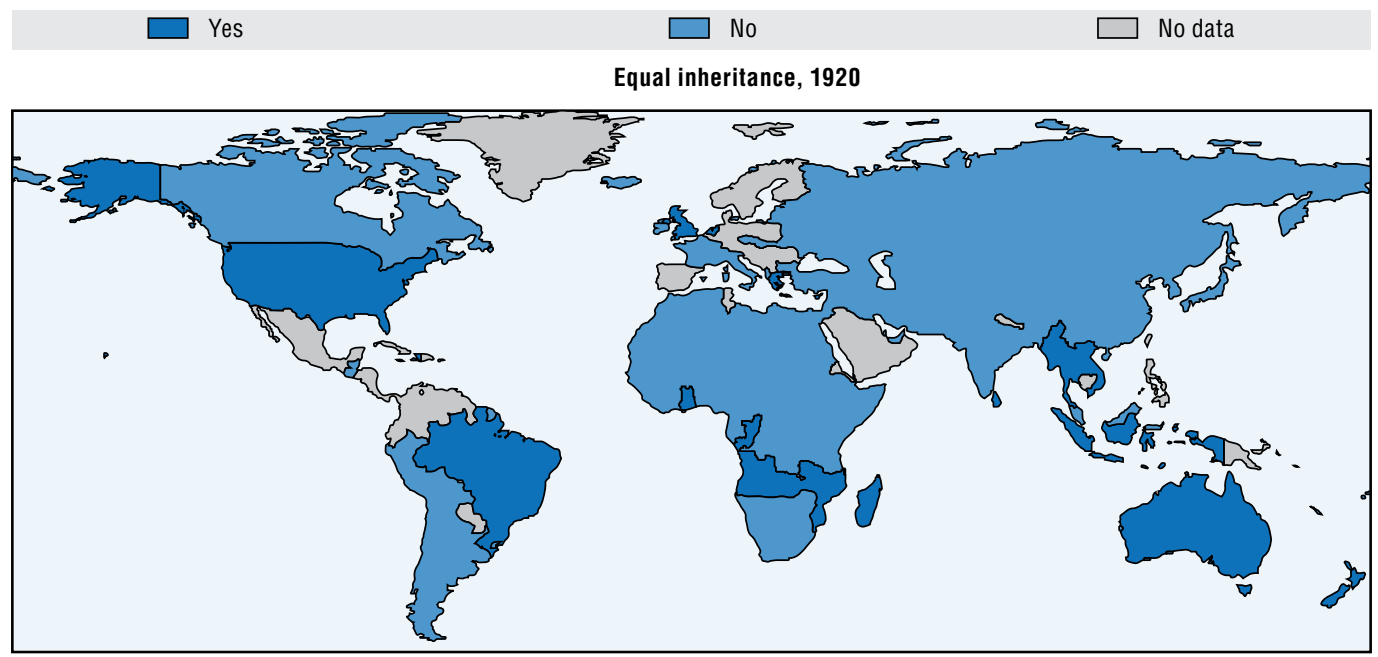

Equal inheritance, 1980

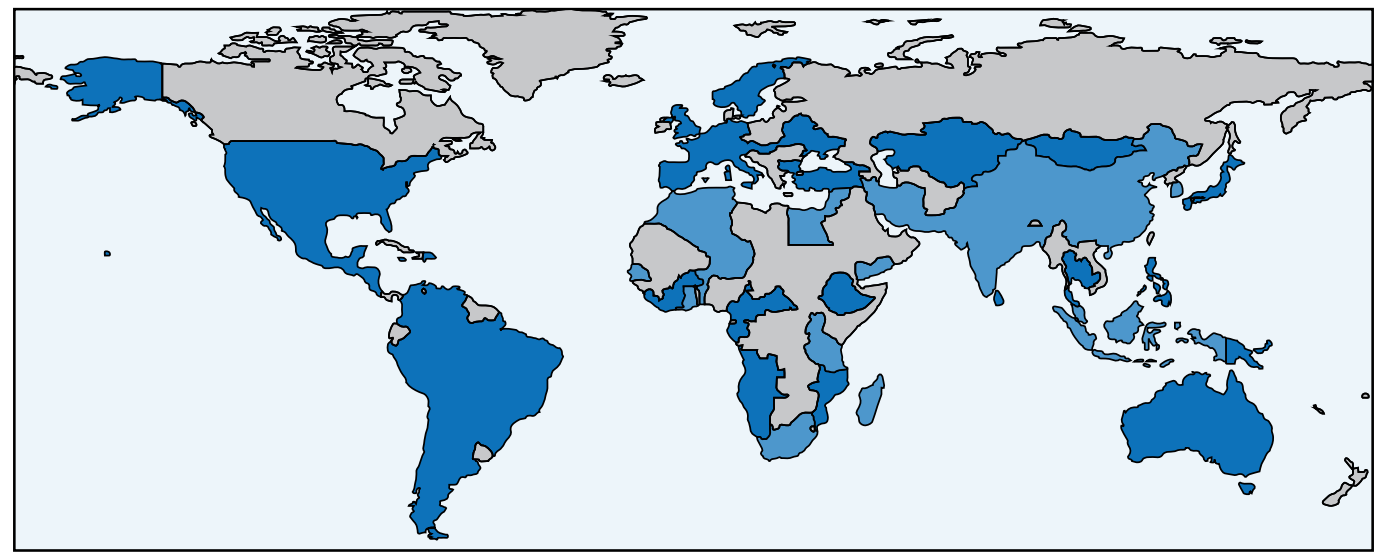

Equal inheritance, 2000

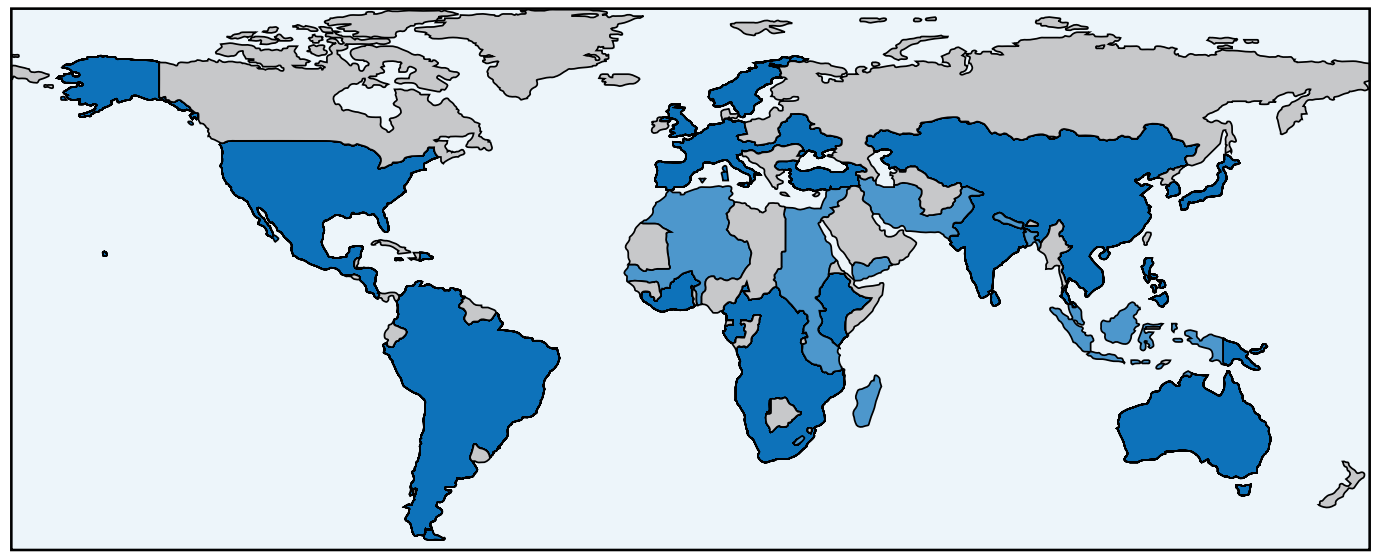

Note: For an assessment of data quality, see Table 12.2. Source: Clio-Infra, www.clio-infra.eu.

When considering the gap in years between when men and women recieved suffrage rights, the formal institutional structure and the overall inequality in a society are important explanatory factors. For instance, in Sub-Saharan Africa most of the post-colonial countries 
Figure 12.3. Countries with female suffrage, 1913, 1950, 2000

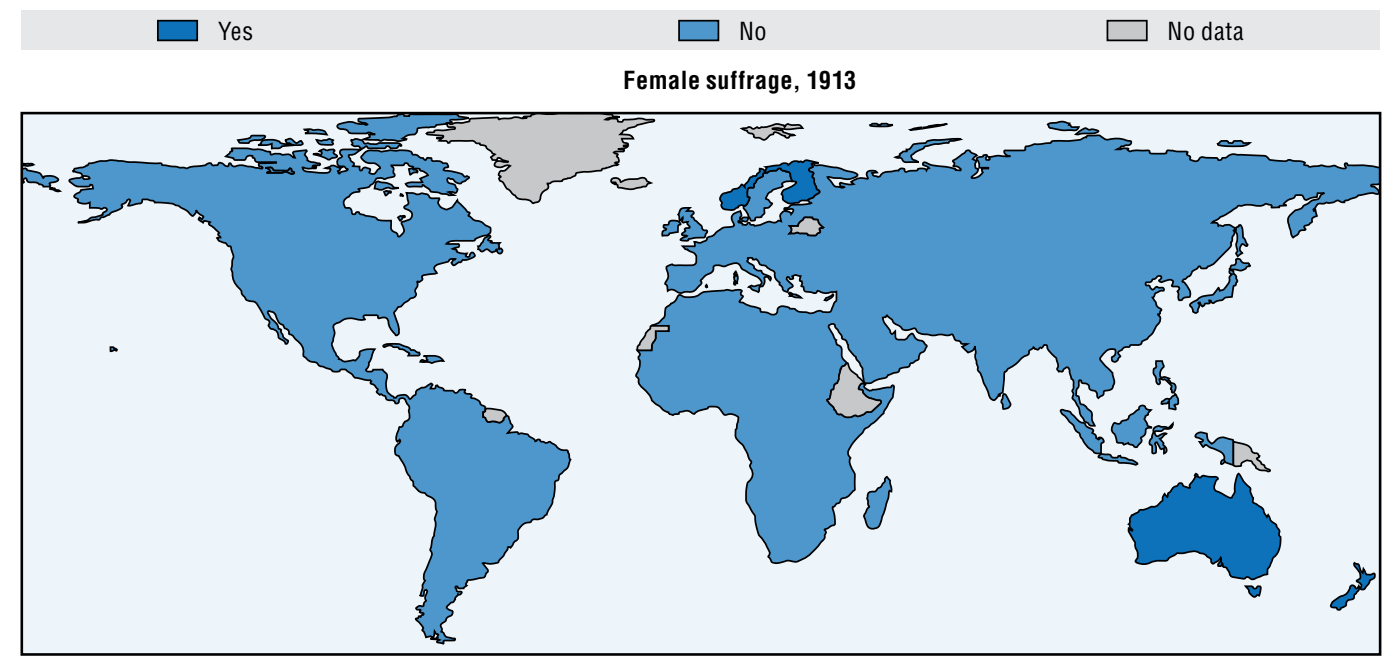

Female suffrage, 1950

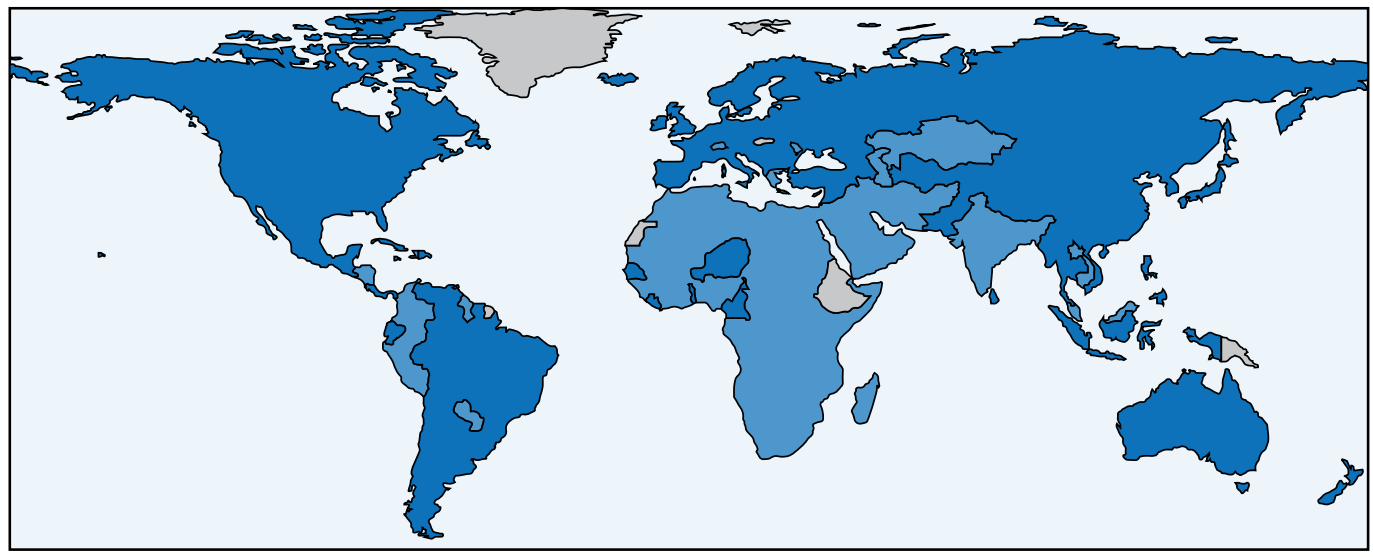

Female suffrage, 2000

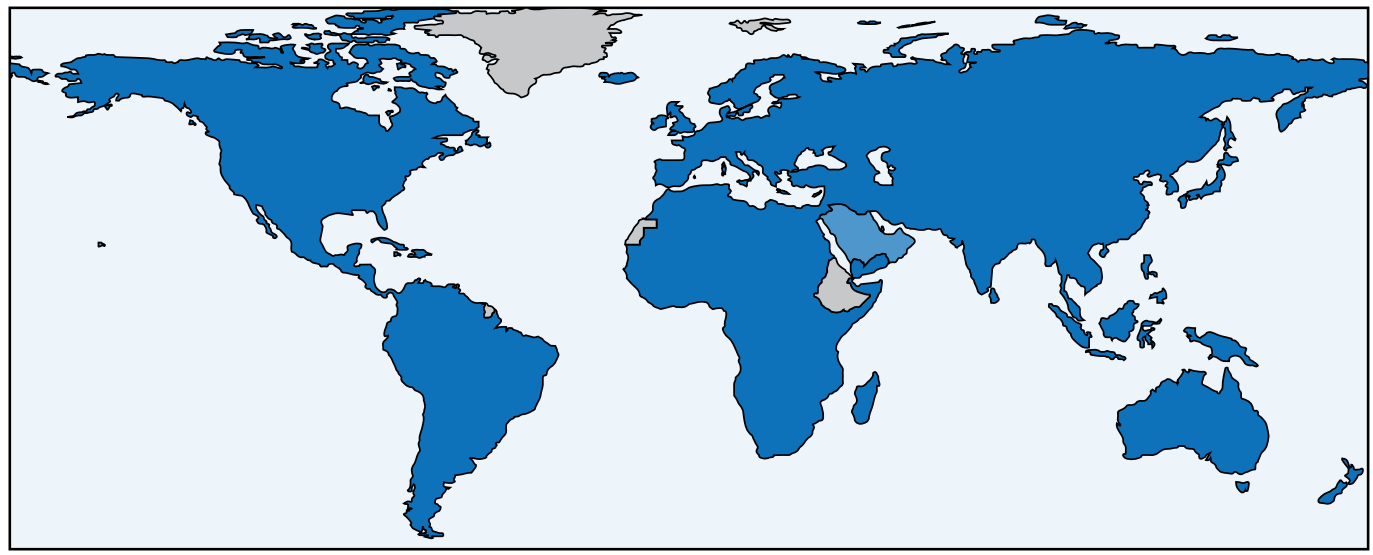

Note: For an assessment of data quality, see Table 12.2. Source: Clio-Infra, www.clio-infra.eu. 
Figure 12.4. Female suffrage, 1895-2000

Number of countries

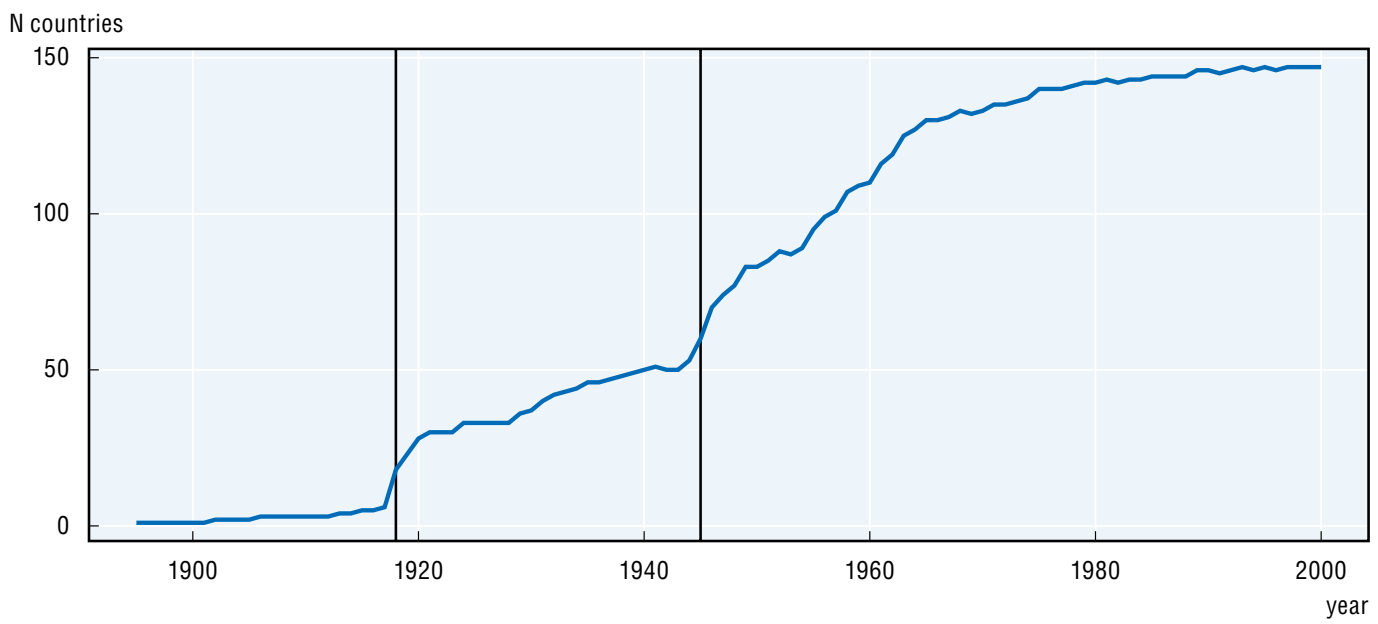

Note: For an assessment of data quality, see Table 12.2.

Source: Clio-Infra, www.clio-infra.eu.

granted men and women the vote either simultaneously (for the first democratic elections) or in quick succession (such as in the case of Gambia 16. whereas in Latin America and many Western European countries a large gap exists between when men and women got the vote (relying on the data from Przeworski, 2009). Some of these Western European countries (e.g. England) and its Offshoots (e.g. United States) had already established forms of liberal democracy in the early 19th century (Marshall et al., 2010). During most of the 19th century, however, countries that had a legislative election restricted the right to vote to adult men who owned property, had an income or paid taxes (Przeworski, 2009; Sokoloff and Engerman, 2000). Therefore in these cases it is hard to argue that gender-specific discrimination existed. Yet the democratisation experience of some countries hints at the fact that gender-related institutions are also a relevant factor in explaining the gap in voting rights between men and women. For instance, in the case of Switzerland, although the first parliament was established in 1848 and universal suffrage to men was granted in 1879 (i.e. without any eligibility restrictions), women gained the right to vote only in 1971. Similar examples can be found in the MENA region where there is a large gap between when the extension of male and female suffrage occurred, as in the case of Saudi Arabia.

Turning now to the variables for which there are data that can be plotted over time, the next section presents trends across regions and the world in the ratios of the various indicators and highlights absolute outcomes where they are of interest. The variables are discussed in the following order: life expectancy, sex ratios, marriage age ratios, educational attainment and then the composite indicator.

There have been significant improvements in life expectancy in recent decades (Table 12.3). This is visible both from the individual country trends and the overall world average. Since 1960, countries such as Afghanistan and India, which were characterised by lagre gender differences in life expectancy, have almost closed the gap. This can also be seen in the statistics for South and Southeast Asia, which move from a more than 1-year difference in life expectancy in favour of men in 1900 (28.92 compared to 27.66) to almost four years in favour of women in 2000 (65.3 compared to 69.3). 
Table 12.3. Gains in life expectancy at birth by gender, 1950-2000

Years

\begin{tabular}{lcc}
\hline \multirow{2}{*}{ Region } & \multicolumn{2}{c}{ Gain in life expectancy at birth } \\
\cline { 2 - 3 } & Men & Women \\
\hline Eastern Europe (EE) & 8.1 & 10.3 \\
Western Offshoots (WO) & 9.8 & 9.4 \\
Western Europe (WE) & 9.9 & 11.1 \\
Sub-Saharan Africa (SSA) & 10.2 & 9.2 \\
Latin America and Caribbean (LA) & 17.6 & 20.0 \\
South and South-East Asia (SSEA) & 19.7 & 21.7 \\
East Asia (EA) & 21.5 & 24.3 \\
Middle East and North Africa (MENA) & 23.2 & 23.6 \\
\hline
\end{tabular}

Note: For an assessment of data quality, see Table 12.2.

Source: Clio Infra, www.clio-infra.eu.

Looking at the gains that have been made in life expectancy over the last 50 years of the 20th century reveals some interesting patterns. It becomes immediately evident that the regions that have made the most progress in increasing both female and male life expectancy are the MENA, East Asia, and South and Southeast Asia. In East Asia and South and Southeast Asia, the progress in the life expectancy of women was more rapid than that of men. These countries also came from levels of male and female life expectancy of below 50 years (apart from East Asia where female life expectancy stood at 53 years in 1950). A disappointing performer in this context is Sub-Saharan Africa, where life expectancy for men in 1950 was just shy of 40 years and that for women stood at 42.78 years. The gains the region has made, relative to other regions with similarly low levels, are comparatively small and that for females is the lowest globally. There was less scope for improvement in Europe (both East and West) and in the Western Offshoots, as in 1950 life expectancies for both men and women were around 60 or above. Here Eastern Europe is the disappointing performer. In 1950, life expectancy there was just under 60 years for men and 65 for women (compared to 66.5 and 71 for Western Europe). Seen in this context the increase achieved in the period from 1950 to 2000 leaves it considerably behind its European counterpart. A different facet of this development can also be observed in Figure 12.5.

The regional graphs show that for Eastern Europe, Western Europe and the Western Offshoots, the ratio of women' to mens' life expectancy has converged on a ratio in the 1.05-1.08 range. Some argue that the lower male life expectancy reflected in such a ratio is due to societal factors that encourage men to adopt riskier life styles, and hence reflects an inherent gender bias against men (Waldron, 1967). However, the life expectancy difference is something that is found across mammal species, and there is evidence to show that it finds its origins in slower ageing by the female of the species and, at least in humans, to greater resistance to disease and lower mortality rates at all ages for women (CluttonBrock and Isvaran, 2007; Kalben, 2000; and Austad, 2006). The UNDP in its calculations of its gender equality indices even goes so far as to assume that due to biological advantages women will live on average five years longer than men, and the Global Gender Gap report uses a ratio of 1.06 as its benchmark for equality. This makes sense if gender equality is seen as a situation where men and women achieve equal development outcomes insofar as there are no sound biological reasons for them not to do so (for more information see Anand and Sen, 1993; Eskes and Haanen, 2007; and Austad, 2006). 
Figure 12.5. Ratio of life expectancy at birth of women to men by region, 1900s-2000s

Decadal averages
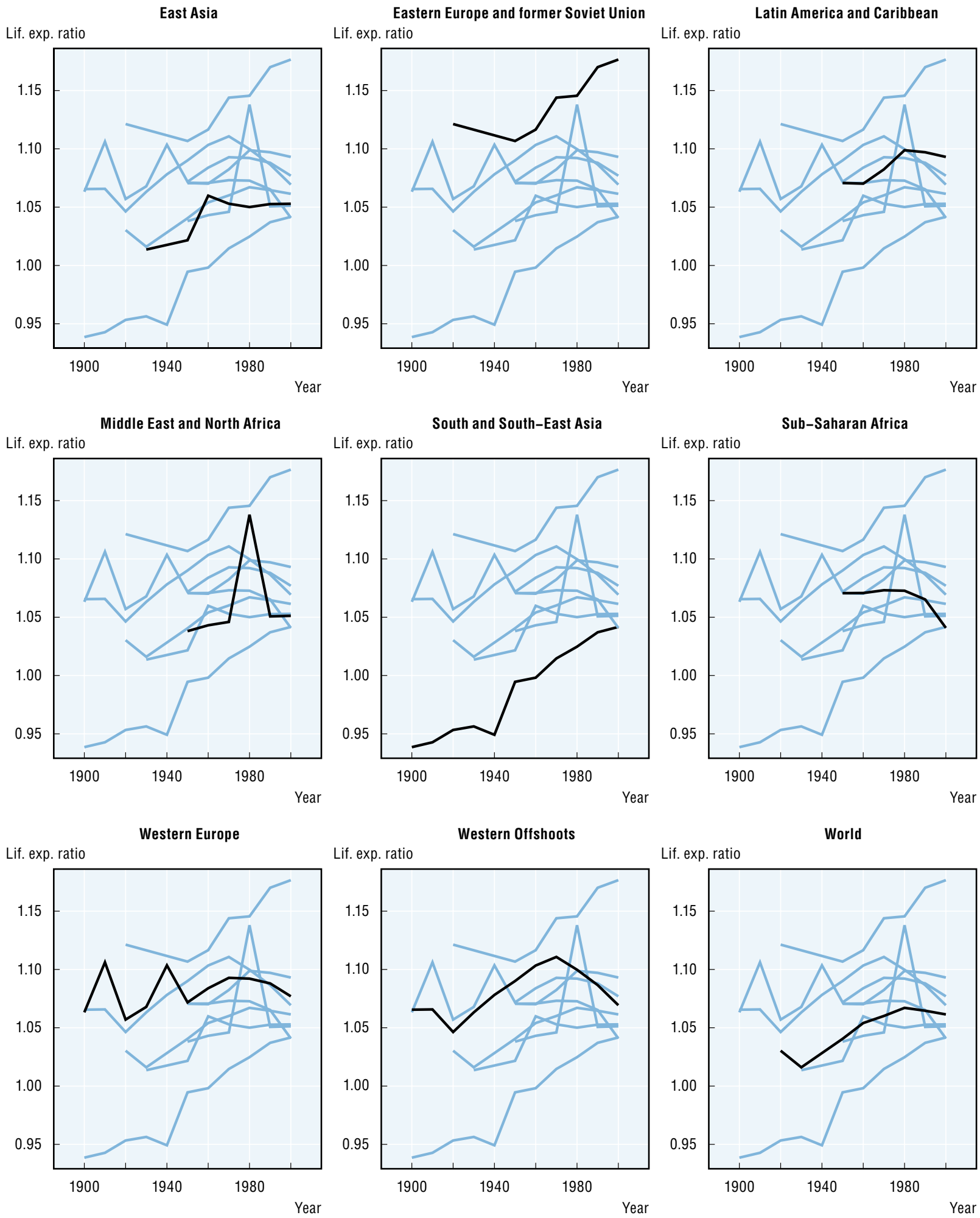

Note: For an assessment of data quality, see Table 12.2.

Source: Clio-Infra, www.clio-infra.eu. 
In the case of Eastern Europe this ratio has even been exceeded. Women in this region have made especially great progress in life expectancy, leading to one of those instances where gender inequality now even reflects a disadvantage for men, although male life expectancy has not fallen in this region. If we look at how the average life expectancy of Eastern European men (67.4 years in 2000) ranks against that of men in other regions of the world, only two regions score lower (Sub-Saharan Africa at 50.13 and South and Southeast Asia at 65.3). Western European men live almost ten years longer than their Eastern European counterparts, wheras the gap for women in the two regions is just under six years. Ours would not be the first study to show that Eastern European men are at a heightened risk of mortality. The reasons for this are often attributed to life style factors, largely related to tobacco and alcohol consumption (McKee and Shkolnikov, 2001; Rehm et al., 2007). All other regions (apart from Sub-Saharan Africa) have also made progress in closing the gap for this indicator, with South and Southeast Asia (SSEA) making the most marked progress. However the SSEA, the MENA and Sub-Saharan Africa have not managed to catch up with the rest of the world.Yet many of the world's regions can be observed to be converging towards a global average gap of 1.05 years, reflecting a nearuniversal advantage of women in life expectancy.

When we look at sex ratios, a different picture emerges (Figure 12.6). For instance, the position of women in both India and China, when measured this way, has declined sharply. China saw its sex ratio fall rapidly after the introduction of the one-child policy in 1979, from 0.94 female infants for every male infant to 0.83 female infants for every male in 2003. In India, the decline began in the 1930s, with a fall from 1.02 females to males at birth to 0.92 females to males in 2003. However, in other countries there was progress toward gender equality in terms of sex ratios. For instance, Brazil experienced progress starting from the 1870s, and Turkey started to close the gap in gender ratios from 1930 onwards. Both of these countries were initially below the world average.

Turning to the regional graphs two things become clear. First, in the modern literature it has been shown that at birth the ratio between females and males should be about 0.94. The data presented above is for infants aged 0-5. Therefore, presuming that the 0.94 ratio is a biological norm, what we see in the regional data is that in the early stages of development the higher sex ratios for children aged 0 to 5 illustrates that more boys than girls die in infancy. The arguments made as to why male-biased sex ratios at birth have emerged often revolve around higher male mortality in the early years of life. This aspect of the graphs is therefore not surprising, and the world average graph, to some extent, reflects the better survival chances of male infants thanks to modern medicine. However, the more important picture that emerges is the substantial worsening of sex ratios for women, reflected in the massive drops in East Asia, to a level where there are 85 girls for every 100 boys in the 0-5 age category, and the more moderate drop in South and Southeast Asia. This is driven by the behaviour in India and China described above.

Turning now to the ratio of marriage ages, there are large cross-national differences in the ages at which men and women marry on average (Figure 12.7). In the most recent observations, Gambia and Egypt have the largest gender differences in marriage ages, while the gap is smallest in Sweden and Japan. Moreover, although the cross-national differences seem to be the result of a long-term process, and progress towards gender equality has been limited, countries such as India, Japan, South Africa and Mexico have nevertheless made headway in this measure of equality. 
Figure 12.6. Ratio of girls to boys aged 0-5 by region, 1900s-2000s

Decadal averages
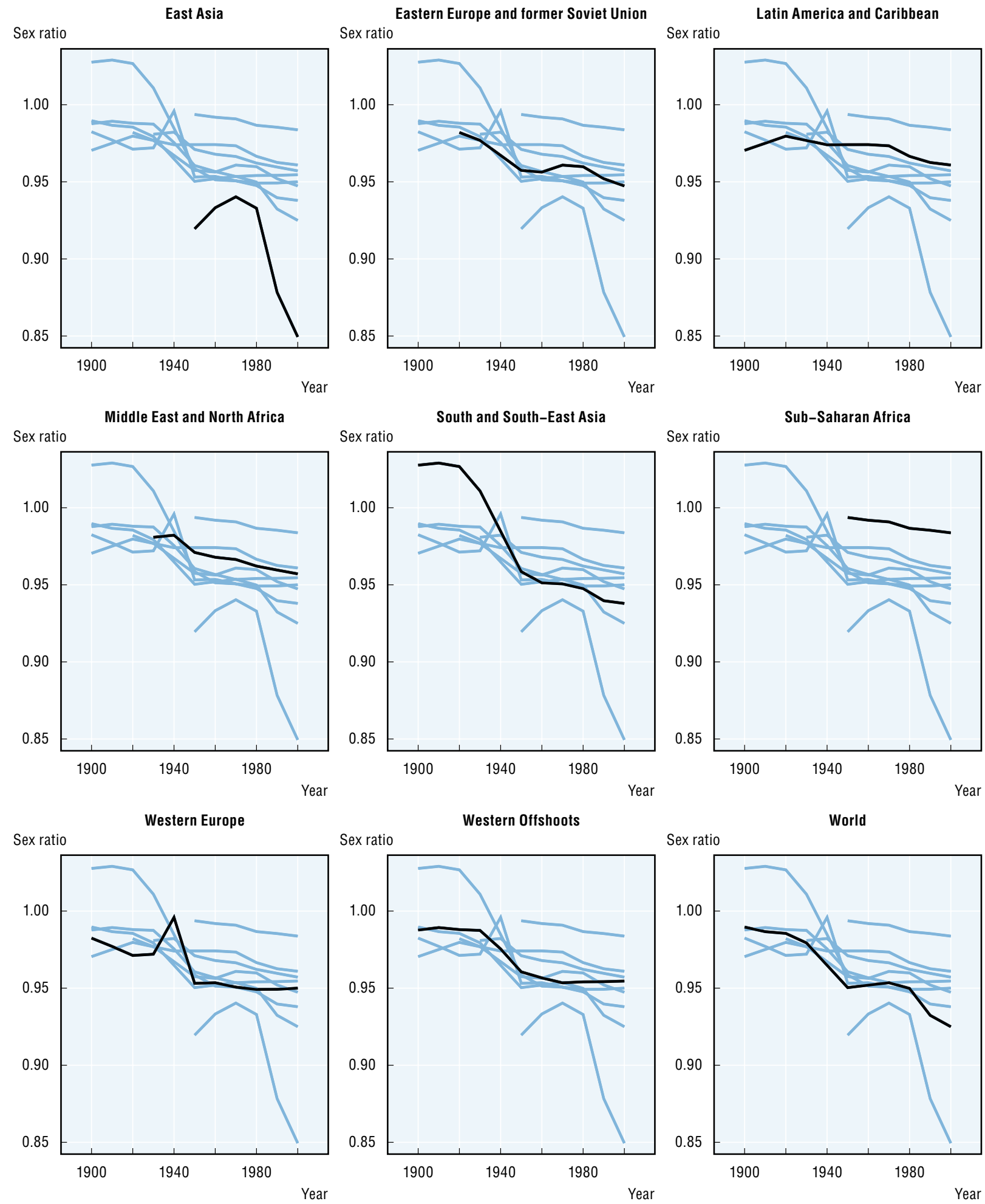

Note: For an assessment of data quality, see Table 12.2

Source: Clio Infra, www.clio-infra.eu. 
Figure 12.7. Ratio of ages at marriage between women and men by region, 1900s-2000s Decadal averages

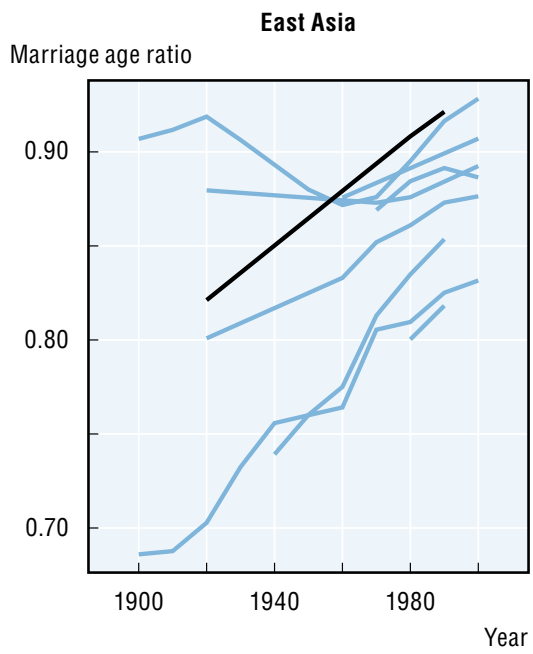

Middle East and North Africa Marriage age ratio

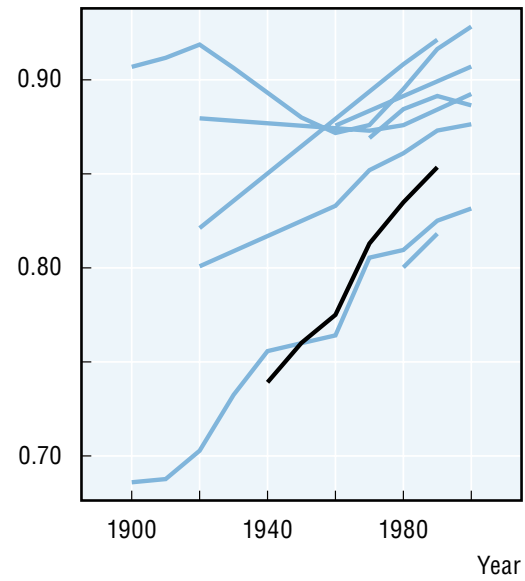

Western Europe

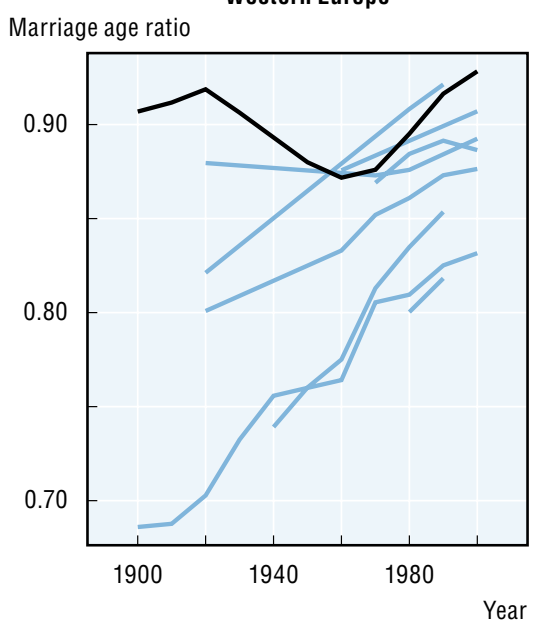

Eastern Europe and former Soviet Union Marriage age ratio

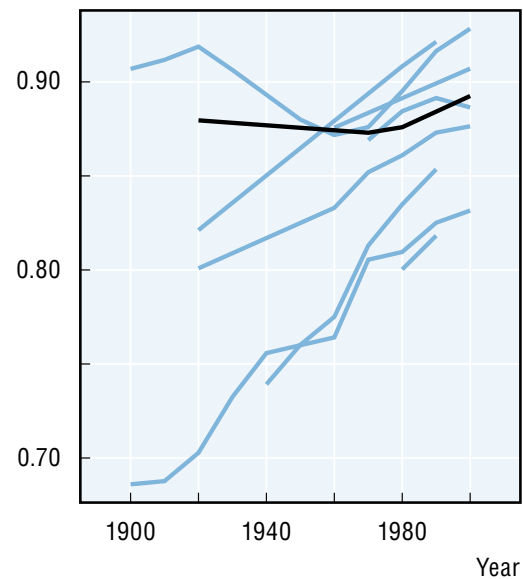

South and South-East Asia Marriage age ratio

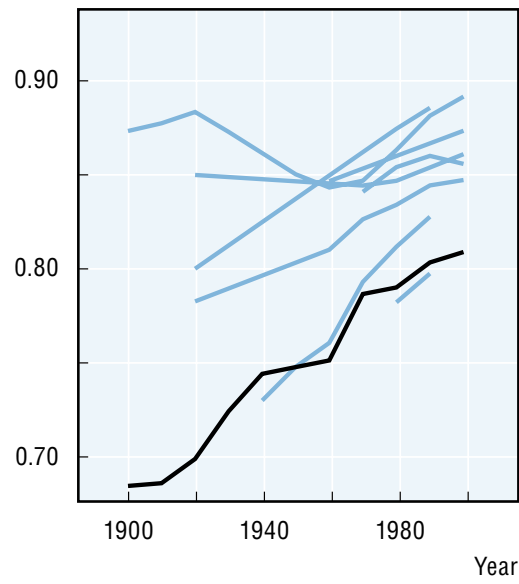

Western Offshoots

Marriage age ratio

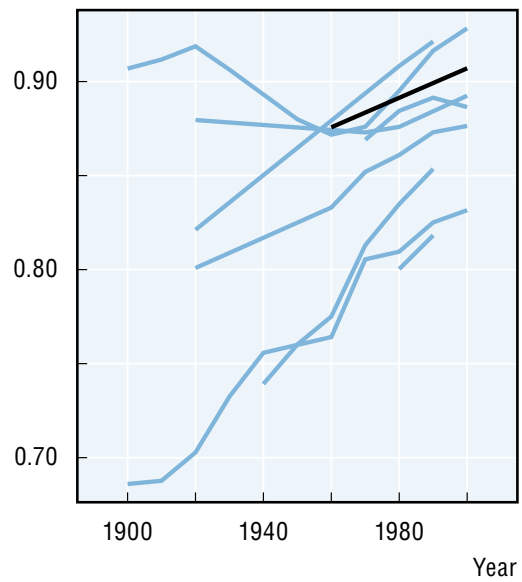

Latin America and Caribbean Marriage age ratio

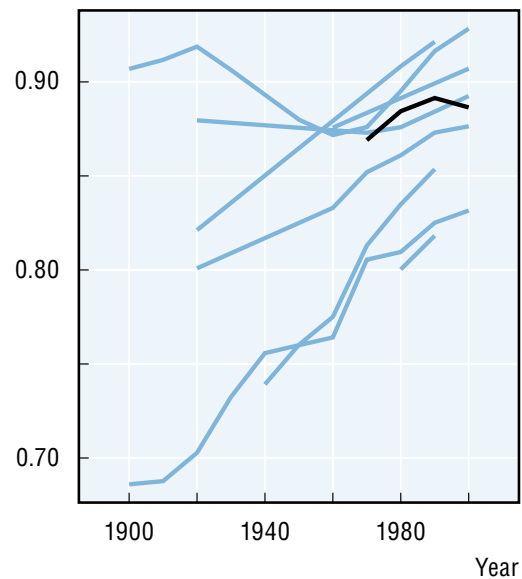

Sub-Saharan Africa Marriage age rati

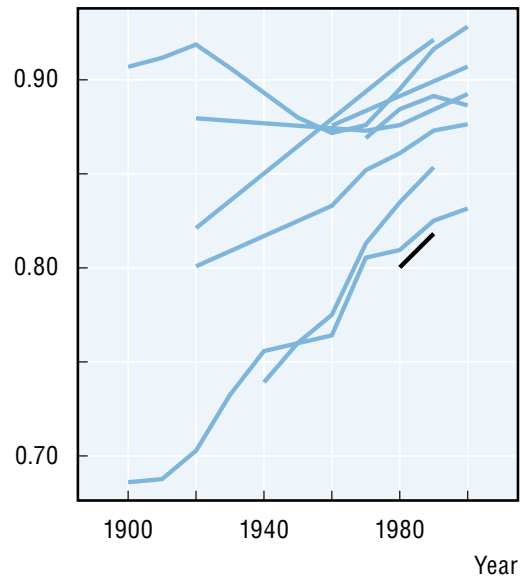

World

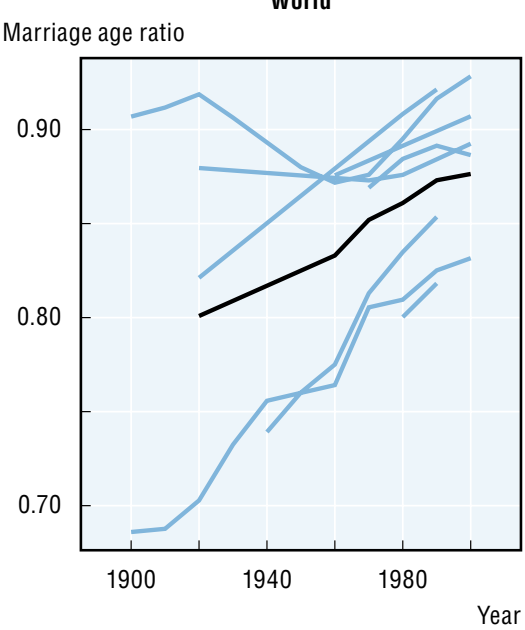

Note: For an assessment of data quality, see Table 12.2.

Source: Clio Infra, www.clio-infra.eu. 
The regional graphs present a mixed picture. East Asia and the MENA have made headway in narrowing the age gap between husand and wife, while Western Europe experienced first a decline and then an increase for this ratio. We see that Sub-Saharan Africa continues to hang behind the other regions. Lastly, a large difference continues to exist between the various regions of the world. This observation coincides closely with the findings of Casterline et al. (1986), who demonstrate that spousal age gaps reflect underlying cultural preferences closely related to concepts of patriarchy, which likely explain the persistent gaps. At the same time marriage ages themselves are sensitive to economic developments and therefore fluctuate over time.

Looking at gender inequalities in education (Figure 12.8), the last five decades have witnessed significant improvements in terms of closing the gender gap, except in the Western Offshoots where there was no gender gap in the 1950s to begin with. The greatest progress in closing the gap was made in the MENA region, although the countries of Asia and Sub-Saharan Africa have also shown remarkable progress. The countries of the former USSR, Latin America and Western Europe have also closed the gender gap in education over the last 50 years. Moreover, since the 1990s there has been a trend for women's outcomes in education to surpass those of men, and in some countries women achieve higher levels of education than men. This is the case in parts of Western Europe (e.g. England, Sweden) and its Offshoots (e.g. Australia, United States). Among the developing economies, Kenya and India made substantial progress in catching up with developed countries in terms of gender equality. In the MENA region, Egypt also made great progress in closing the gender gap in education, but progress was limited in Yemen and Afghanistan.

This progess toward gender equality in education is inextricably linked with the overall progress made in educational attainment, where inequality in years of schooling between and within countries is found to be rapidly decreasing (Murtin and Murrison, 2013). Since 1950, the average years of schooling of the population aged 25 and above has increased substantially around the world. In South and Southeast Asia and the MENA, average years of schooling have more than doubled since the 1980s. To take the example of female education, in South and Southeast Asia, educational attainment for the female population aged 25 and above increased from an average of 1.43 years in 1950 to 3.45 years in the 1980s, and was at a level of 5.15 years by the 2000s. The MENA region made the most progress in increasing average female education attainment, from an average of 0.91 years in the 1950s to an average of 5.71 years in the 2000s.

With respect to women's rights in politics, despite improvements over the course of the 20th century, women's participation in national parliaments remains one of the major challenges in achieving gender equality globally: not even one-quarter of the world's parliamentarians are women (Figure 12.9). Despite this persistent gap, the past century has been witness to some considerable progress. The most progress can be observed in Western Europe, Eastern Asia and Eastern Europe and the countries of the former Soviet Union. The case of Eastern Europe and the former Soviet Union is particularly interesting, considering the sharp decline in female members of parliament after the collapse of the Union and the subsequent widening gender gap. Former Soviet countries, which were once near the top in the world rankings of female representation, have now fallen far behind Western Europe, and even behind many developing countries. This marked decline is due to the removal of the quota system implemented by the Communists, after the Union had collapsed (Saxonberg, 2000). Other regions of the world have shown considerable progress 
Figure 12.8. Ratio of average years of education between women and men by region, 1950s-2000s Decadal averages

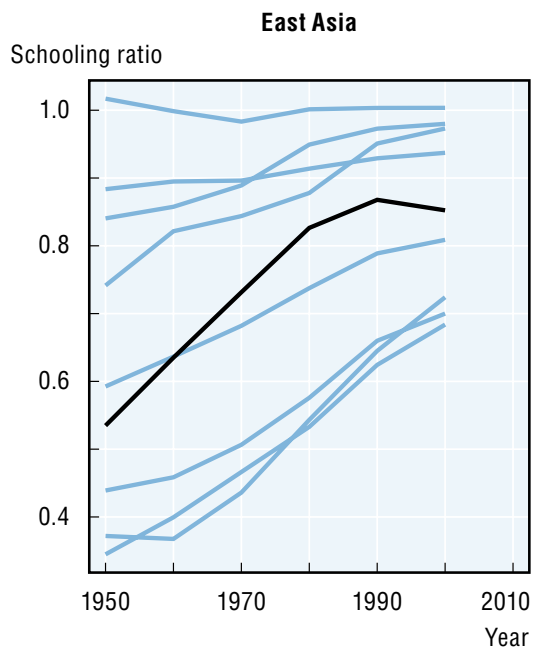

Middle East and North Africa

Schooling ratio

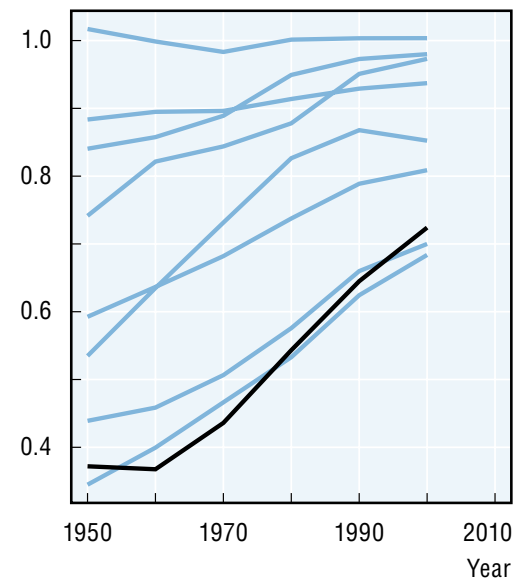

Western Europe

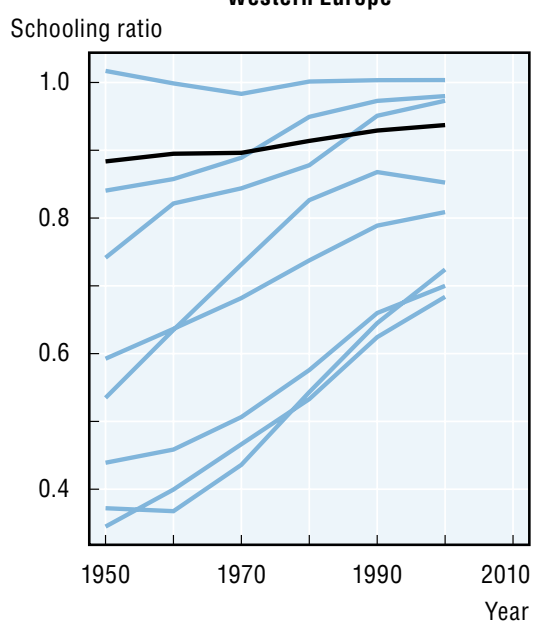

Eastern Europe and former Soviet Union Schooling ratio

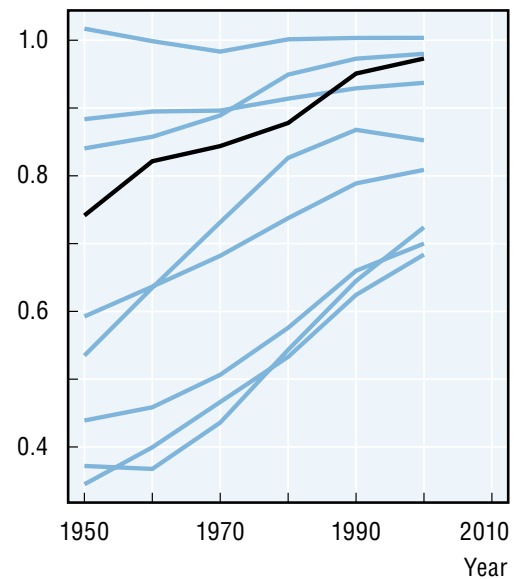

South and South-East Asia Schooling ratio

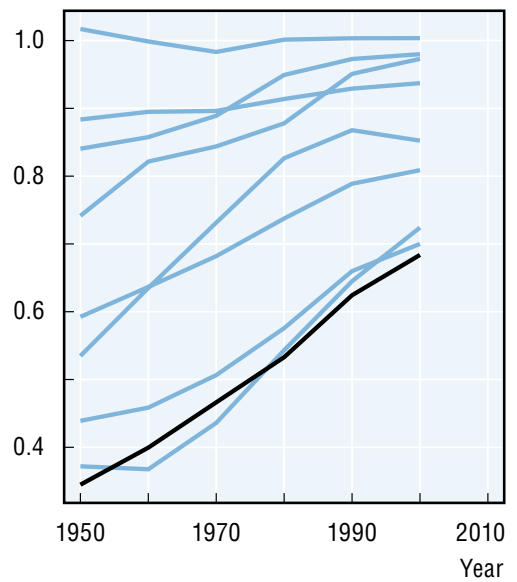

Western Offshoots

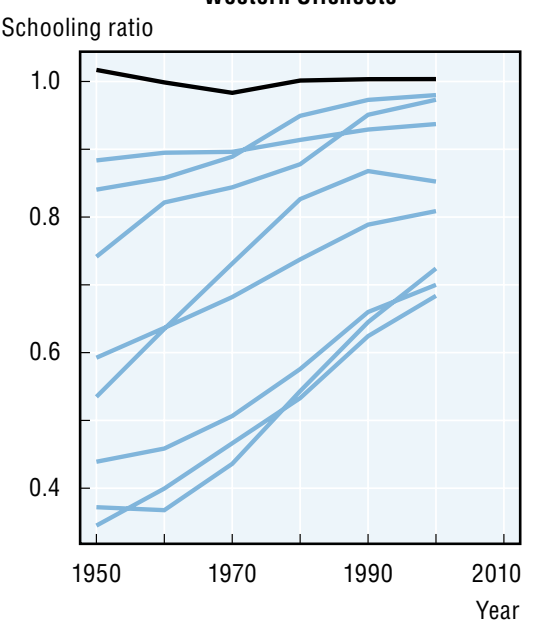

Latin America and Caribbean Schooling ratio

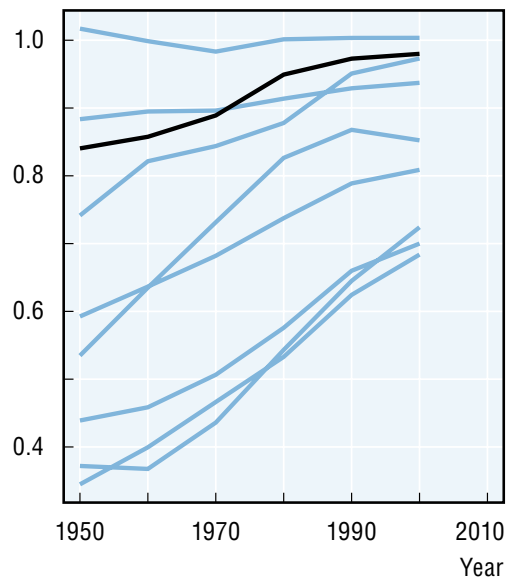

Sub-Saharan Africa

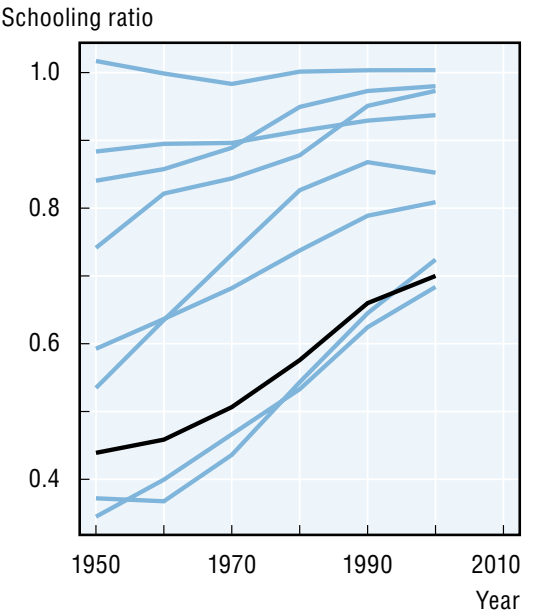

World

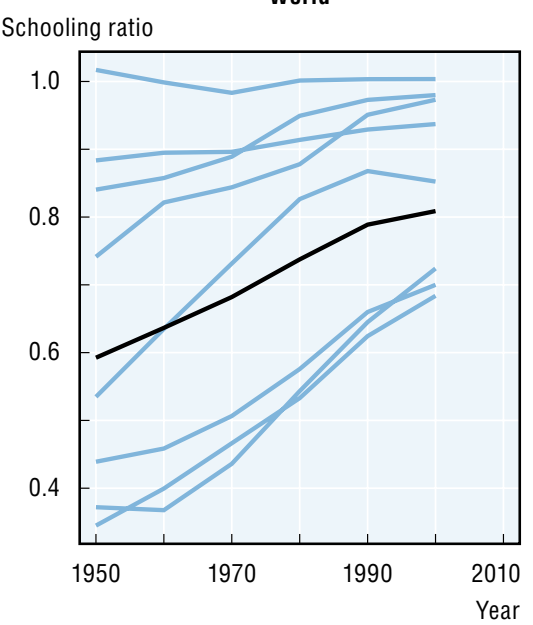

Note: For an assessment of data quality, see Table 12.2.

Source: Clio Infra, www.clio-infra.eu. 
Figure 12.9. Ratio of parliamentary seats held by women and men by region, 1900s-2000s

Decadal averages

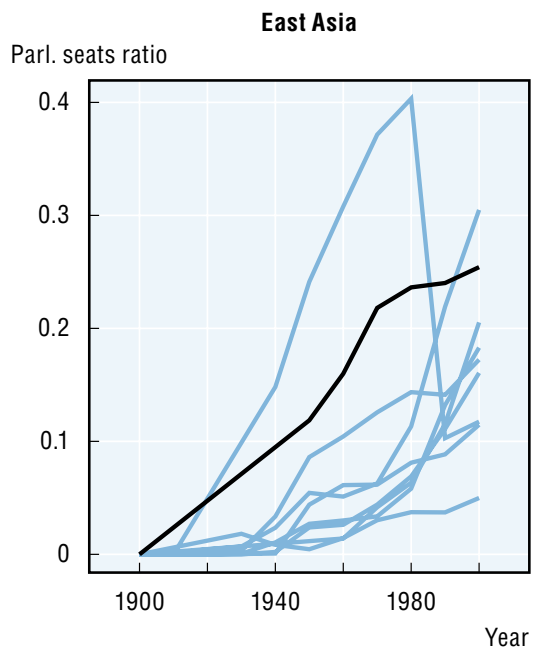

Middle East and North Africa

Parl. seats ratio

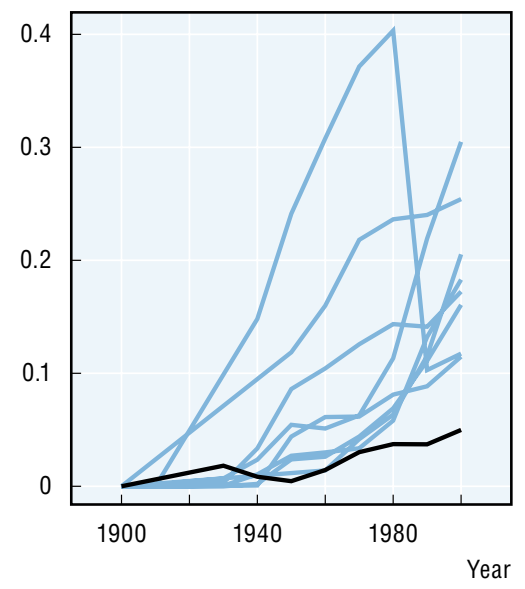

Western Europe

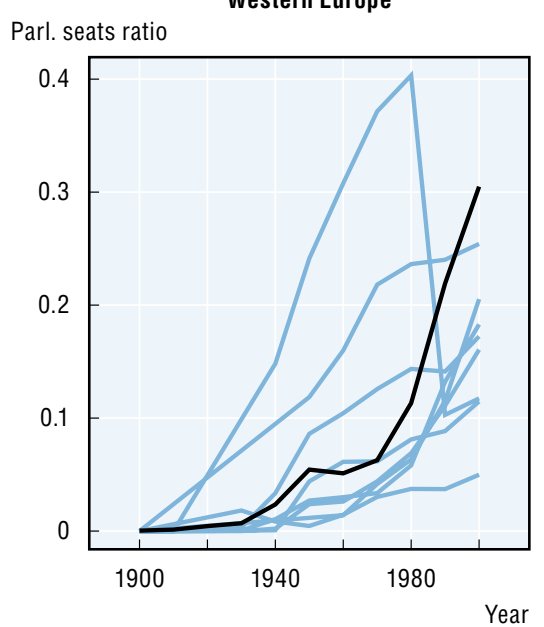

Eastern Europe and former Soviet Union Parl. seats ratio

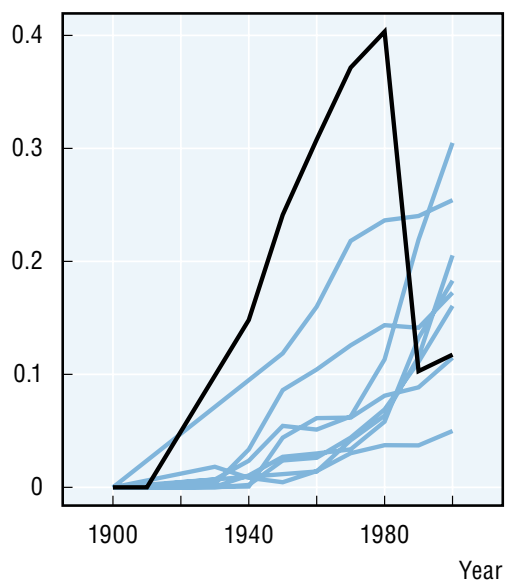

South and South-East Asia Parl. seats ratio

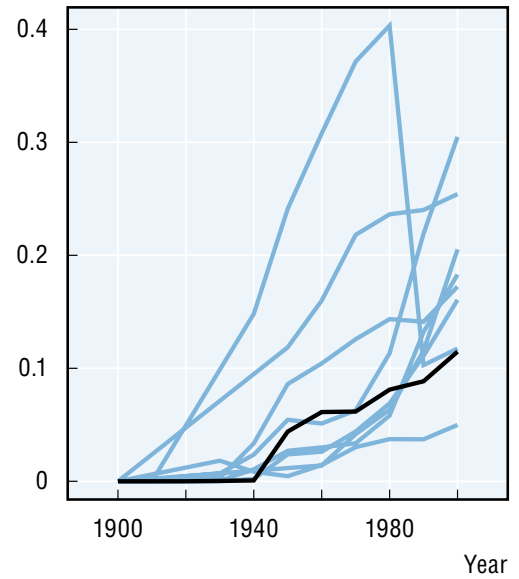

Western Offshoots Parl. seats ratio

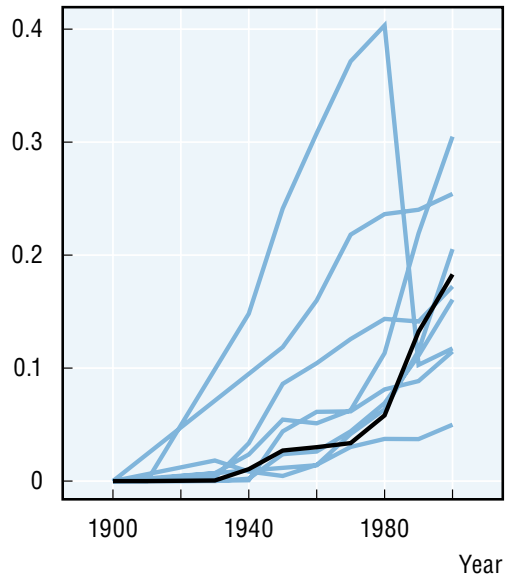

Latin America and Caribbean Parl. seats ratio

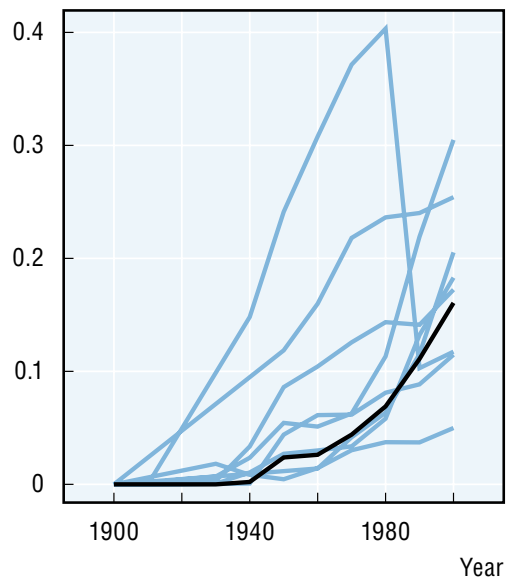

Sub-Saharan Africa

Parl. seats ratio

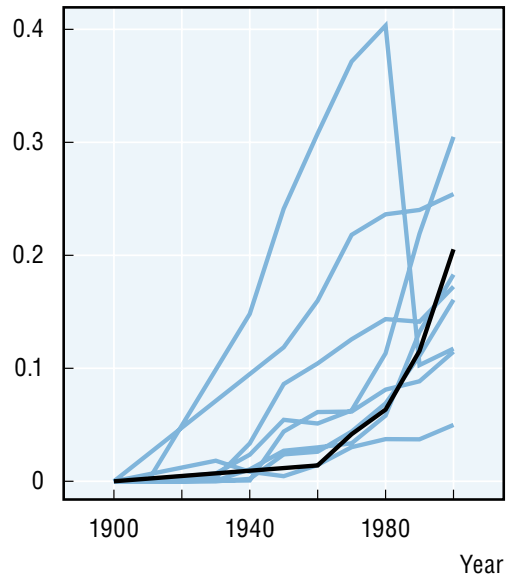

World

Parl. seats ratio

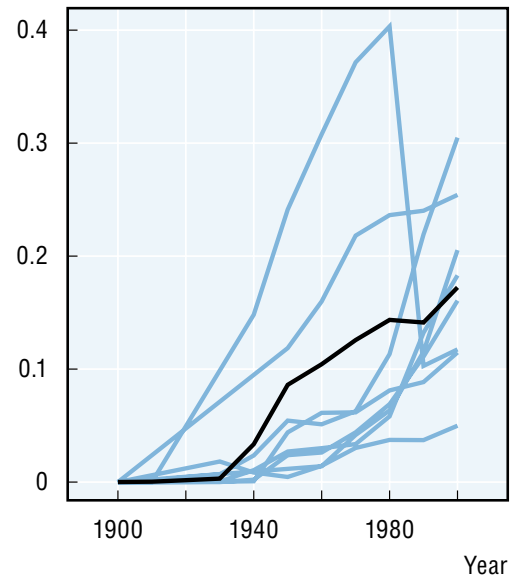

Note: For an assessment of data quality, see Table 12.2.

Source: Clio Infra, www.clio-infra.eu. 
on this measure from the 1950s onwards, except for the MENA. The quota system seems to be an important determinant of the position of women in parliament. This is exemplified in Rwanda, which achieved the highest percentages of women in parliament after the introduction of a quota system in 2002. With $44 \%$ of its parliamenterians being women, Rwanda outperformed even Sweden, one of the few countries that has made continous progress towards closing the gender gap in parliament (without a quota system).

Lastly, we provide an overall view of how countries are performing when the measures we describe above are evaluated together. This composite index is available from 1950 to 2003 (Figure 12.10). After a slow start in the 1950s, the gender equality measure exhibits a steady trend upwards, which can be observed for all the world's regions. However, it should also be noted that global progress was limited. At a global average of 68 (out of a possible 100 ) in 2000 , gender equality was still well short of the theoretical maximum. The regional averages reveal further failings in achieving gender equality. The figure shows that the highest gender equality scores are found in Western Europe, its Offshoots, and East Asia. Gender equality was substantially lower in the Middle East and North Africa, Latin America and Southern Asia. Remarkably, Sub-Saharan Africa is in the middle of the group of world regions, a reflection of measuring equality between genders, rather than their absolute performance.

Figure 12.10 shows, as do the individual components, that there was progress in terms of gender equality everywhere, but that there were important persistent regional differences. Only Latin America and the Caribbean closed the gap with Western Europe and its Offshoots. The MENA remained the least gender egalitarian region throughout the 19502003 period. Furthermore, although East Asia and Eastern Europe made some progress towards gender equality, after the 1980s these regions experienced a reversal of this trend. Though Sub-Saharan Africa is seen to make absolute progress towards gender equality over the period, the gap between it and the leading regions has increased. (Dilli et al. 2014b).

\section{Correlation with GDP per capita}

This section examines the relationship between gender equality indicators and economic development. As explained in the introduction, over the past 20 years researchers and policy-makers have started to pay more attention to gender equality as one of the core drivers of economic development. Tertilt (2005), for example, concludes that enforcing a ban on polygyny decreases fertility by $40 \%$, increases the savings rate by $70 \%$, and increases output per capita by $170 \%$. In another recent study, Branisa et al. (2013) provide empirical evidence that social institutions related to higher gender inequality are associated with lower female secondary education, higher fertility rates, higher child mortality, and a higher perceived level of corruption in a country. However, these studies mainly provide crossnational evidence rather than evidence over time. But has there been a positive association between gender equality and development, captured by GDP per capita, throughout the course of the 20th century?

Figure 12.11 illustrates that the relationships between the single indicators of gender inequality and GDP per capita differ from each other and change over time. The relationship between sex ratios and GDP per capita became weaker over time, and even negative after the 1940s (for a discussion, see below). The relationship between inequality in life expectancy and GDP per capita was positive and relatively strong from the early 20th century onwards. Among our indicators, marriage patterns seem to have the strongest persistent relationship with GDP per capita, starting from the 1850s onwards, with a positive link between the two 
Figure 12.10. Regional averages of the composite gender equality index, 1950s-2000s Index where 100 is perfect equality, decadal averages

East Asia

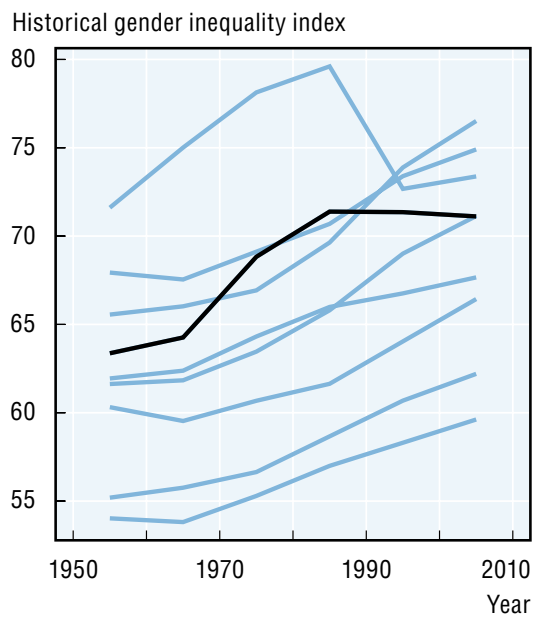

Middle East and North Africa

Historical gender inequality index

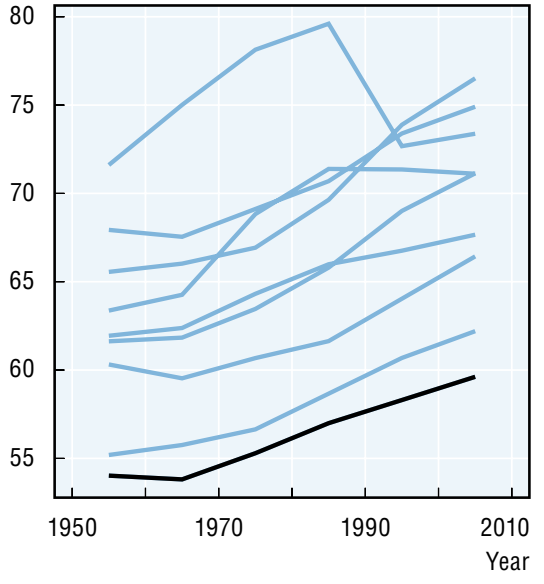

Western Europe

Historical gender inequality index

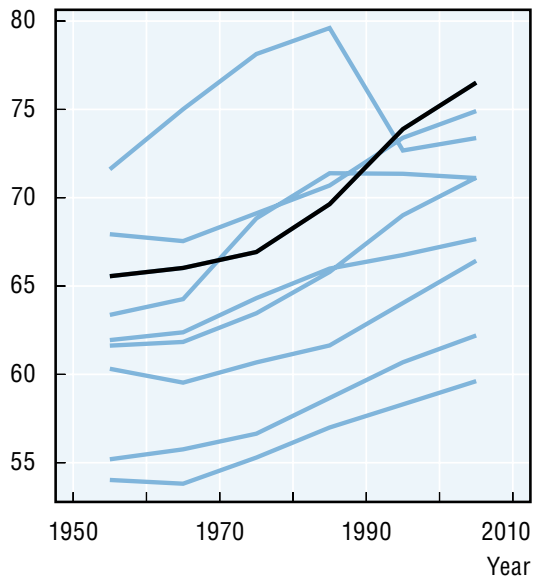

Eastern Europe and former Soviet Union Historical gender inequality index

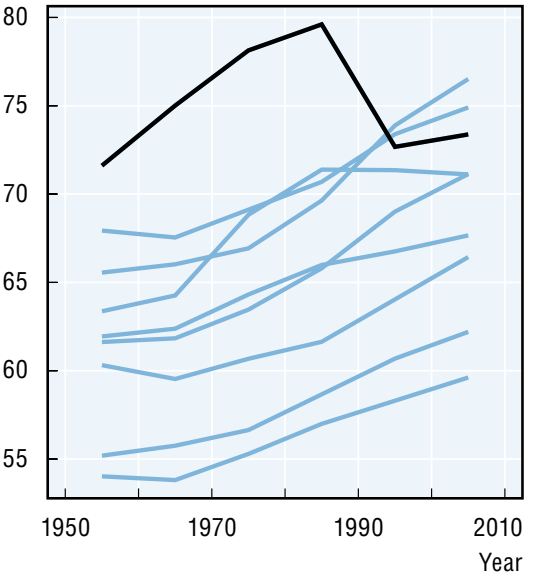

South and South-East Asia

Historical gender inequality index

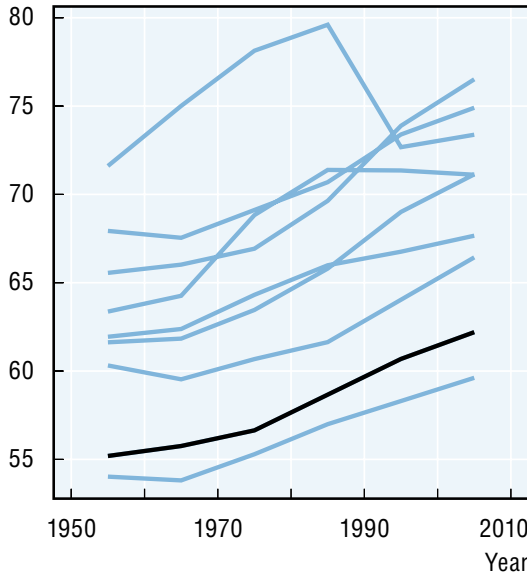

Western Offshoots

Historical gender inequality index

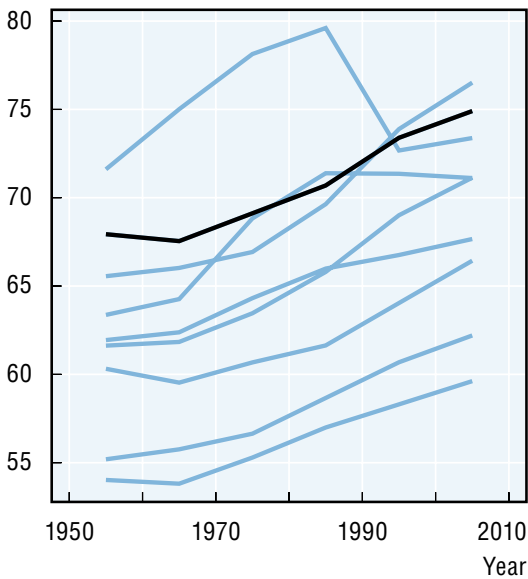

Latin America and Caribbean

Historical gender inequality index

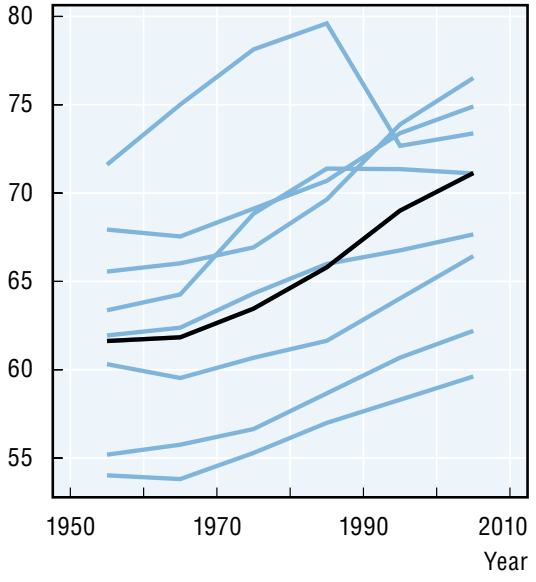

Sub-Saharan Africa

Historical gender inequality index

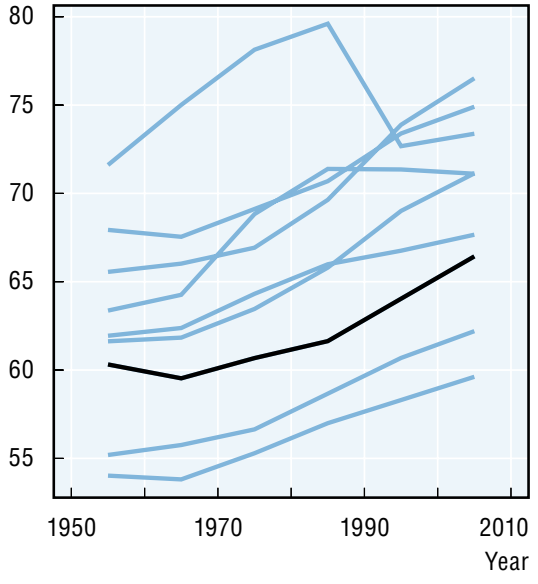

World

Historical gender inequality index

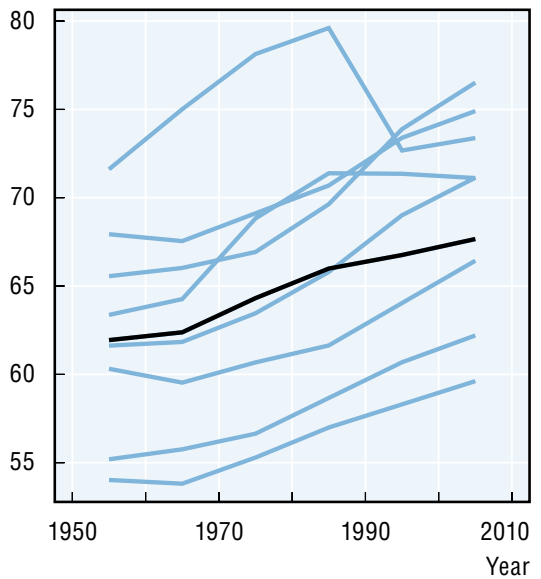

Note: For an assessment of data quality, see Table 12.2.

Source: Clio Infra, www.clio-infra.eu. 


\section{Figure 12.11. Correlation between gender equality indicators and GDP per capita, 1900s-2000s}

Pearson correlation coefficient and upper/lower bounds of $95 \%$ confidence interval per decade

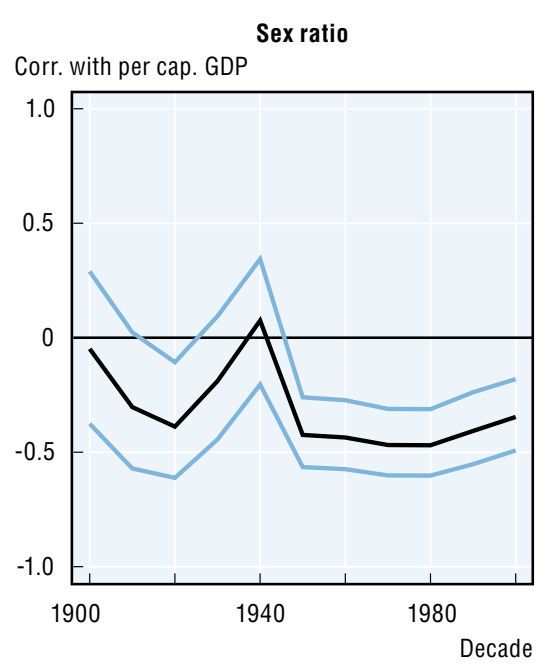

Schooling ratio

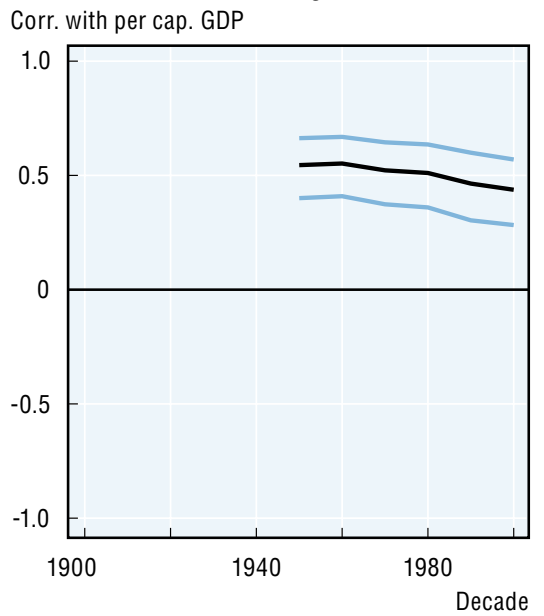

Lif. exp. ratio Corr. with per cap. GDP

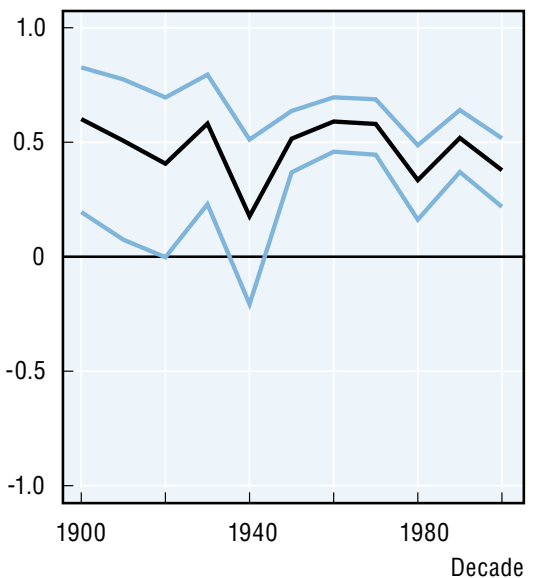

Parl. seats ratio Corr. with per cap. GDP

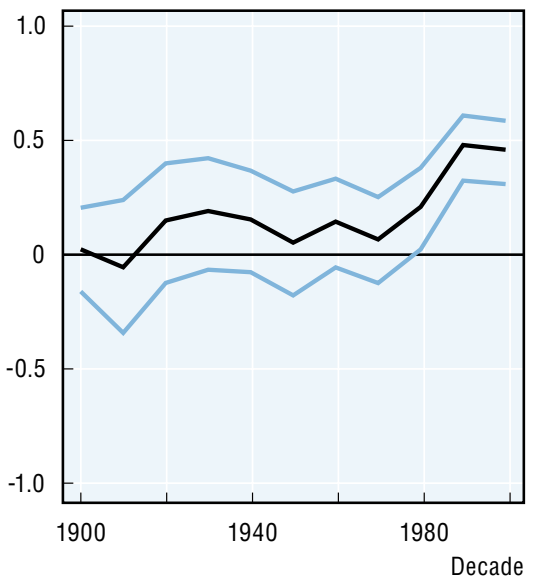

Marriage age ratio Corr. with per cap. GDP

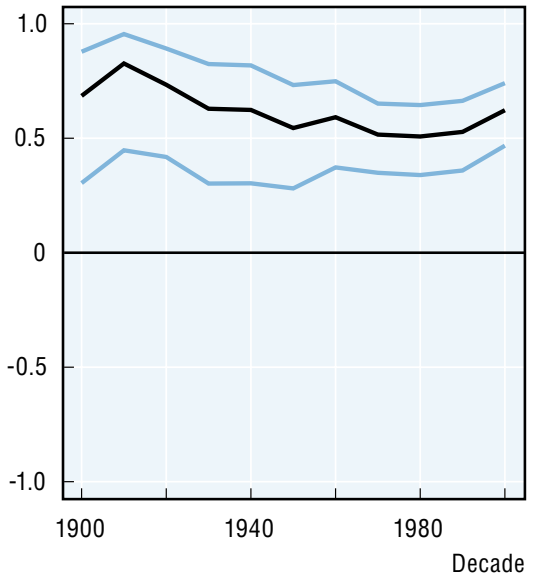

Historical Gender Equality Index Corr. with per cap. GDP

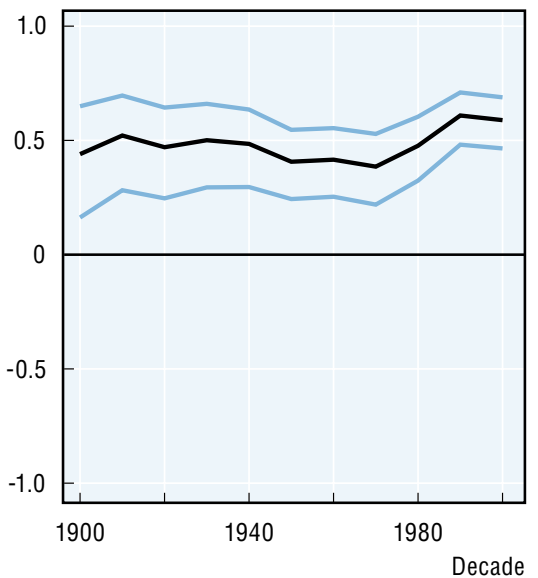

Note: For an assessment of data quality, see Table 12.2. Source: Clio Infra, www.clio-infra.eu.

remaining observable throughout the period. Gender equality in parliament also seems to be positively related to GDP per capita, but only after the 1970s. An explanation for this might be sought in the fact that the parliamentary activity of women remains limited everywhere. Looking at the relation between our overall composite index and GDP, again the relation between the two seems to get stronger after 1970, which is likely to be partly driven by the improvements in gender equality in terms of education and parliamentary activity.

The relationships between the various indicators of gender inequality and GDP per capita are largely positive. The weakly negative association of sex ratios with per capita GDP is the one exception to this rule. The reason for this negative relationship between GDP per capita and the ratio of female to male infants may lie in improved paediatric care. The sex ratio at birth is generally around 1.06 male infants to every female infant. 
Historically this ratio was balanced out over the life course by the fact that young boys had a higher mortality due to their biologically determined vulnerability at young age. However, modern medicine eliminated this mortality bias. This relationship is also likely to be due to the practices mentioned above in countries such as India and China, where increased wealth and access to modern technology are used to achieve unequal gender treatment of infants before they are even born by means of sex selective abortion.

Another way of presenting the relationship of the various measures of gender inequality and GDP per capita is to plot them against each other directly. This excludes a direct visualisation of the time element, so is not a dynamic analysis, but it gives a sense of how the various measures of gender inequality relate to GDP per capita across different levels of development. The results of plotting the data this way are shown in Figure 12.12. These plots can also reveal any nonlinear relationship between gender equality and economic development (Mammen and Paxson, 2000; Friesen et al., 2012), which are not directly evident from Figure 12.11. Note first that we do not look at female labour force participation, for which the non-linear relationship is well-established (Goldin, 1995). This investigation of the underlying data reveals a number of non-linearities. For one, the relation between per capita GDP and gender inequality is often strongest at lower income levels (below 5000 dollars per capita). Life expectancy ratios, sex ratios, schooling ratios and marriage age ratios all have a strong association with per capita GDP in this range. The relationships level off substantially at incomes above 5000 dollars. Taking the logarithm of GDP per capita can often capture this relationship well. The ratio of female to male members of parliament is the one exception and is characterised by a linear relationship with GDP per capita.

To sum up, this chapter has illustrated trends in the well-being of women compared to men across the globe over the past century. Although we still live in a world where women are, on average, disadvantaged relative to men, the situation seems to have improved in the second half of the 20th century, especially from the 1980s onwards. Looking at the dimensions separately, the good news is that gender equality has been achieved - and for some countries surpassed - in terms of life expectancy and that some progress has been made in closing the gender gap in marriage ages, although structural differences remain between different regions. In many developed countries, parity has also been achieved in educational attainment. However, there is still much scope for progress in all the other dimensions. Women's participation in politics remains a point of particular concern around the world, even for countries in Western Europe and its Offshoots. The lack of progress on this measure is even more striking once regional differences are taken into account. While worldwide average female parliamentary representation in 2010 stood at 17 per cent, the average for the MENA was only five per cent. Missing girls and the associated skewed sex ratios remain a major challenge for China and India.

Overall, two main messages can be taken from the current chapter. First, significant progress did take place over the 20th century in terms of achieving gender equality, but there is still a long way to go as gender gaps persist in many dimensions. Second, regional differences in gender equality are not a recent phenomenon but have deep historical roots.

\section{Priorities for future research}

This chapter provided an historical perspective on women's well-being. Clearly, the availability of historical data plays a crucial role in influencing which dimensions this overview could discuss. More historical data and analysis are needed to understand the development 


\section{Figure 12.12. Various indicators of gender equality and GDP per capita, 1900s-2000s}

Ratios and US dollars at 1990 PPP, decadal averages
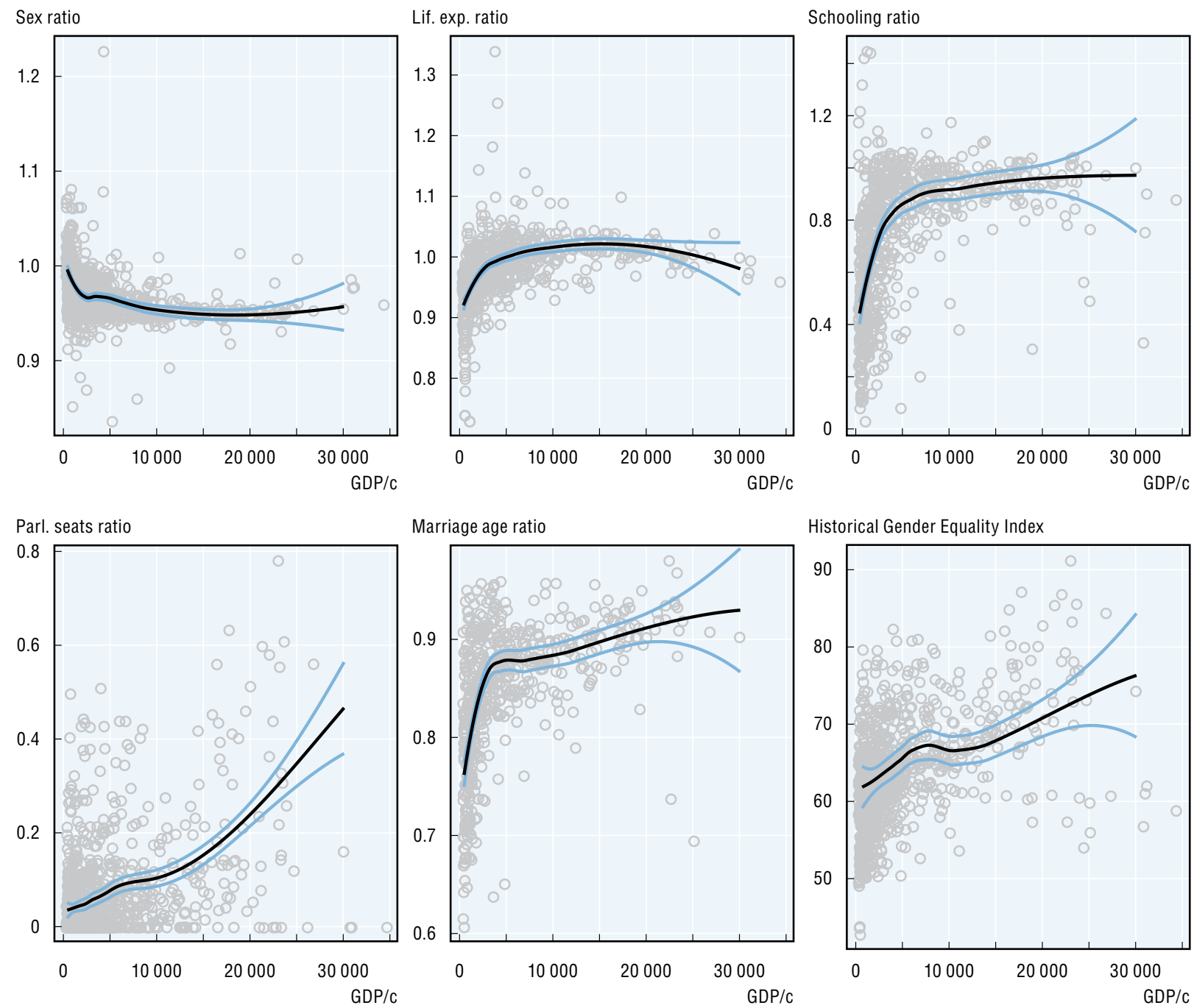

Note: For an assessment of data quality, see Table 12.2.

Source: Clio Infra, www.clio-infra.eu.

and the causes of gender equality/inequality over the past century. Areas where new data and analysis would be particularly useful include educational attainment disaggregated by gender before 1950 and female labour force participation. Another priority for future research is to collect data on female wages so as to have a better understanding of the socio-economic dimensions of women's well-being and position. Moreover, violence against women is one of the most crucial fields where gathering historical data is highly desirable. Although this aspect is harder to capture with quantitative data, mortality data, which indicate the cause of death, would be a good starting point to provide an historical perspective on this issue.

Geographical coverage is another issue that future research should ideally take into consideration, in particular for Sub-Saharan Africa. Generally, data only becomes available for Africa starting from the 1950s onwards, and data is still scarce for many countries in this region today. Similar issues of data scarcity exist for the East Asian and MENA 
regions. These regions are of particular importance as they are still poor performers in the various dimensions of women's well-being highlighted in this chapter. A longer historical perspective would provide insights to help researchers and policy-makers better understand the drivers of these gender inequalities so as to achieve the goal of gender equality in these regions.

Lastly, further valuable insights into the well-being of women could be gained by breaking down the national data on women's well-being into indicators that reflect sociodemographic and economic status. The size of the gender gap may differ significantly between different social groups, and therefore indicators at a less aggregate level could provide further understanding of the drivers of gender inequality. A good starting point would be censuses and/or micro data where detailed information on various aspects related to the well-being of women can be found.

\section{Notes}

1. Take the United Nations Millennium Development Goals as an example: of the 8 goals, 6 can be linked more or less directly to female empowerment, with the last two also having elements that can be achieved only through tackling female empowerment. See United Nations (2013) for an overview of how the UN perceives the gender dimension of the MDGs. For the World Bank's take on the matter, see the Gender Equality as Smart Economics Project, World Bank.

2. See Dilli et al. (2014a). This list is non-exhaustive. For example, improved female education has been shown to reduce infant mortality, improve household efficiency and reduce fertility (see Dollar and Gatti, 1999; King and Hill, 1997; Rosenzweig and Schultz, 1982).

3. It should be noted that gender inequality can also be used to denote a situation where men are disadvantaged vis-à-vis women (as nowadays can be observed in some countries in the case of certain measures of educational attainment or of health status); however, as this is historically almost never the direction in which the inequality runs, the bulk of this chapter looks at how gaps disadvantageous to women have been closed over the past century. This is also to address an imbalance in the rest of the book by which almost all the other chapters either are focused on men or provide no data on indicators disaggregated by gender.

4. Others include the Gender Empowerment Index by the UNDP, the Social Institutions and Gender Index by the OECD, the Global Gender Gap Index by the World Economic Forum and the Women's Economic Opportunity Index produced by the Economist Intelligence Unit.

5. The UN uses a correction of five years because there is some evidence to show that at a biological level women have a greater life expectancy. However, Klasen (2004) argues that, "[a]s no society, past or present, treated the two sexes equally and the two sexes did not differ in survival-related behaviours, it is hard to separate biology from behaviour. Thus it is hard to say whether females 'should' enjoy a longevity advantage of 3, 4, or five years".

6. Views vary on whether income and labour force participation are relevant indicators related to women's well-being. Klasen (2004) argues that it is not immediately clear that gender inequalities in labour force participation should necessarily be seen as relevant for a well-being assessment, as it might be the result of a consensual division of labour within the household.

7. While the UNDP's Gender Empowerment Measure and the World Economic Forum's Global Gender Gap Index take such factors as accessibility of skilled or high-paid jobs into consideration, the indicators used here cover the majority of the elements of the UN's Gender Related Development Index and the replacement Gender Inequality Index.

8. One issue with internationally comparable indicators is that they are insufficient for many purposes, because they do not provide information on the socio-cultural environment, including culture and embedded social relationships (Malhotra, Schuler and Boender, 2002; Bartlett, 2004; Oxaal and Baden, 1997; Ibrahim and Alkire, 2007).

9. For a more detailed discussion of the issue, see Branisa et al. (2009).

10. The year men were granted the right to vote is defined as the year where universal suffrage took place, meaning all men could vote regardless of their income, ethnicity or any restrictions, whereas such a distinction has not been made for women. 
11. The Clio-Infra human capital hub aims to create a database on education split by gender on a global basis extending back to the early 19th century. However, this project is not yet complete, and we therefore could not include this data in the current study.

12. More information on the data can be found at Barro-Lee Educational Attainment Dataset.

13. Labour force participation is included as an additional measure in the composite index to capture the socio-economic dimension of women's position. We believe labour force participation is an important aspect of gender equality, as it reflects what one can actually do with better education, etc. The example of the Middle East and North Africa is a case in point. In this region, although the educational level of women increased significantly from the 1980 s onwards, this did not translate into higher labour force participation. For further information on the composite index please see Dilli et al. (2014a).

14. There has been valuable work on women's labour force participation in the historical context for a handful of cases such as England and the Netherlands (see for example Horrell and Humphries, 1995; Schmidt and van Nederveen Meerkerk, 2012). However these studies are limited to a small number of cases, which makes them unsuitable for global comparison, the main focus of our study. In the future it might become possible to make such an analysis by using data to be made available through the History of Labour Relations project at the International Institute for Social History.

15. In the case of the Scandinavian countries we complemented the Murdock data with information on the year in which legislation was enacted to mandate equal inheritance.

16. The exception is Namibia, where universal male suffrage was granted in 1926, while it was extended to women only in 1989, following independence.

\section{References}

Anderon, S. and D. Ray (2010), "Missing women: Age and disease”, The Review of Economic Studies Vol. 77, pp 1262-1300.

Arulampalam, W., L.A. Booth and M.L. Bryan (2007), "Is There a Glass Ceiling over Europe? Exploring the Gender Pay Gap Across the Wage Distribution", Industrial and Labor Relations Review, Vol. 60, pp. 163-186.

Austad, S.N. (2006), "Why Women Live Longer than Men: Sex Differences in Longevity", Gender Medicine, Vol. 3/2, pp. 79-92.

Barro-Lee Educational Attainment Dataset, http://www.barrolee.com/.

Barro, R.J. and J.W. Lee (2010), "A New Data Set of Educational Attainment in the World, 1950-2010", National Bureau of Economic Research, www.nber.org/papers/w1590.

Bartlett, A. (2004), “Entry Points for Empowerment”, CARE Bangladesh, http://expert.care.at/downloads/ careexpert/CARE_Analytical_Toolbox.pdf.

Bolt, J. (2012), “A New Database on the Origins of Institutional Development”, University of Groningen working paper.

Branisa, B., S. Klasen and M. Ziegler, (2013), "Gender Inequality in Social Institutions and Gendered Development Outcomes", World Development ,Vol. 45, pp. 252-268.

Branisa, B., S. Klasen and M. Ziegler (2009), "The Construction of the Social Institutions and Gender Index (SIGI)", Background paper, University of Goettingen, http://genderindex.org/sites/default/files/ SIGI_background_paper.pdf.

Caldwell, J., P.H. Reddy and P. Caldwell (1983), “The Causes of Marriage Change in South India”, Population Studies, Vol. 37, pp. 343-61.

Cammack, M.E. and R.M. Feener (2012), “The Islamic Legal System in Indonesia”, Pacific Rim Law \& Policy Journal, Vol. 13, pp. 13-42.

Cammack, M.E. “Dossier 22: Inching Toward Equality: Recent Developments in Indonesian Inheritance Law" published on the Women Living Under Muslim Law website, http://www.wluml.org/node/336, accessed 19 January 2014.

Carmichael, S. (2011), "Marriage and Power: Age at First Marriage and Spousal Age Gap in Lesser Developed Countries", The History of the Family, Vol. 16/4, pp. 416-36.

Casterline, J. B., L. Williams and P. McDonals (1986), “The Age Difference Between Spouses: Variations among Developing Countries", Population Studies, Vol. 40, pp. 353-374. 
Clutton-Brock, T.H. and K. Isvaran (2007), "Sex differences in ageing in natural populations of vertebrates", Proceedings of the Royal Society, Vol. 274, pp. 3097-3104.

Currie, J. and E. Moretti. (2003). "Mother's Education and the Intergenerational Transmission of Human Capital: Evidence from College Openings." The Quarterly Journal of Economics, Vol. 118/4, pp. 1495-1532.

Dilli, S., A. Rijpma and S. Carmichael, (2014a). "The Gender Gap in a Historical Perspective”, CGEH working paper series, http://cgeh.nl/working-paper-series.

Dilli, S., A. Rijpma and S. Carmichael, (2014b). "Achieving gender equality: development various historical legacies", CESifo Economic Studies, forthcoming.

Dollar, D. and R. Gatti. (1999), “Gender Inequality, Income, and Growth: Are Good Times Good for Women?" Mimeographed, The World Bank.

Dollar, D., R. Fisman and R. Gatti (2001), "Are women really the 'fairer' sex? Corruption and women in government", Journal of Economic Behavior and Organization, Vol. 46/4, pp. 423-429.

Donno, D. and B. Russett. (2004), "Islam, Authoritarianism, and Female Empowerment: What Are the Linkages?” World Politics, Vol. 56/4, pp. 582-607.

Duflo, E. (2012), "Women Empowerment and Economic Development", Journal of Economic Literature, Vol. 50/4, pp. 1051-1079.

Eskes, T. and C. Haanen, "Why do women live longer than men?" European Journal of Obstetrics \& Gynaecology and Reproductive Biology, Vol. 133/2.

FAO (Food and Agriculture Organization of the United Nations) (2011), The State of Food and Agriculture 2010-2011 - Women in Agriculture.

Fish, M.S. (2002), "Islam and Authoritarianism”, World Politics, Vol. 55/1, pp. 4-37.

Friesen, J., J.Baten and V. Prayon, (2012), "Women Count. Gender (In-) Equalities in the Human Capital Development in Asia, 1900-60", University of Tubingen Working Paper Series in Economics and Finance, No. 29, http://tobias-lib.uni-tuebingen.de/volltexte/2012/6040/pdf/WPEF29Friesen_Baten_Prayon.pdf.

Goldin, C. (1995), “The U-Shaped Female Labour Force Function in Economic Development and Economic History", in Schultz, T.P. Investment in Women's Human Capital and Economic Development, University of Chicago Press, pp. 61-90.

Gray, J.S. (1998), “Divorce-Law Changes, Household Bargaining, and Married Women's Labor Supply”, The American Economic Review, Vol. 88, pp. 628-642.

Gray, W.S. (1969), The Teaching of Reading and Writing, Unesco, http://unesdoc.unesco.org/images/0000/ 000029/002929eo.pdf.

Hajnal, J. (1965), "European Marriage Patterns in Perspective”, In Population in History: Essays in Historical Demography, edited by D.V. Glass and D.E.C. Eversley, Edward Arnold.

Hallward-Driemeier, M., T. Hasan and A. Bogdana Rusu (2013), “Women's Legal Rights over 50 Years: Progress, Stagnation or Regression?” World Bank Policy Research Working Paper, 6616, http://papers. ssrn.com/sol3/papers.cfm?abstract_id=2330042.

Horrell, S. and J. Humphries (1995), “Women's Labour Force Participation and the Transition to the Male-Breadwinner Family, 1790-1865”, The Economic History Review, Vol. 48/1, pp. 89-117.

Ibrahim, S. and S. Alkire, (2007), "Agency and empowerment: A proposal for internationally comparable indicators," Oxford Development Studies, Vol. 35/4, pp. 379-403.

Inglehart, R. and P. Norris (2003), Rising Tide: Gender Equality and Cultural Change Around the World, Cambridge University Press.

International Institute for Social History, History of Labour Relations project http://socialhistory.org/en/ projects/history-labour-relations-1500-2000.

Inter-parliamentary Union (2011), Women in National Parliaments, http://www.ipu.org/wmn-e/world.htm, accessed July 2013.

Kabeer, N. (1999), “Resources, agency, achievement: reflections on the measurement of women's empowerment", Development and Change, Vol. 30, pp. 435-464.

Kalben, B.B. (2000), "Why Men Die Younger: Causes of Mortality Differences by Sex", North American Actuarial Journal. Vol. 4/4. 
King, E.M. and M.A. Hill (1997), "Women's Education in Developing Countries: An Overview," in Women's Education in Developing Countries: Barriers, Benefits, and Policies, edited by E. M. King and M.A. Hill, Chapter , pp. 1-50. World Bank Publications.

King, E.M. et al. (1986), Change in the Status of Women across Generations in Asia, Rand Corporation.

Klasen, S. (2002), "Low Schooling for Girls, Slower Growth for All? Cross-Country Evidence on the Effect of Gender Inequality in Education on Economic Development", The World Bank Economic Review, Vol. 16/3, pp. 345-73.

Klasen, S. (2004), “Gender-Related Indicators of Well-Being”, Working Paper Series UNU-WIDER Research Paper, World Institute for Development Economic Research (UNU-WIDER), http://ideas.repec.org/p/ got/iaidps/102.html, accessed January 2014.

Klasen, S. and F. Lamanna (2009), “The Impact of Gender Inequality in Education and Employment on Economic Growth: New Evidence for a Panel of Countries", Feminist Economics, Vol. 15/3, pp. 91-132.

Klasen, S. and C. Wink (2003), “Missing Women”: Revisiting the debate”, Feminist Economics, Vol. 9/2-3, pp. 263-299.

Lagerlöf, J. (2003), “Gender Equality and Long-Run Growth”, Journal of Economic Growth, Vol. 8, pp. 403-426.

Lindert, P.H. (2004). Growing Public: Social Spending and Economic Growth Since the Eighteenth Century, Volume I: The Story, Cambridge University Press.

Lukito, R. (2013), Legal Pluralism in Indonesia: Bridging the Unbridgeable. Routledge.

Lynch, K.A. (2011), “Why Weren't (many) European Women 'missing'?” The History of the Family, Vol. 16/3, pp. 250-266.

Malhotra, A. (2003), “Conceptualizing and measuring women's empowerment as a variable in international development" Measuring Empowerment: Cross-disciplinary Perspectives, Washington, DC, 4-5 February. http://siteresources.worldbank.org/INTEMPOWERMENT/Resources/486312-1095970750368/ 529763-1095970803335/malhotra2.pdf.

Malhotra, A., S.R. Schuler and C. Boender, (2002), Measuring women's empowerment as a variable in international development. World Bank, http://www4.worldbank.org/afr/ssatp/Resources/HTML/GenderRG/Source\%20\%20documents/Technical\%20Reports/Gender\%20Research/TEGEN5\%20Measuring\%20 Women's\%20Empowerment\%20ICRW\%202002.pdf.

Mammen, K. and C. Paxson, (2000), "Women's Work and Economic Development”, The Journal of Economic Perspectives, Vol. 14/4, pp. 141-164.

Marshall, M.G., K. Jaggers and T.R. Gurr (2010), Polity IV Project: Political Regime Characteristics and Transitions, 1800-2010. INSCR, http://www.systemicpeace.org/polity/polity4.htm, February 25, 2011.

McKee, M. and V. Shkolnikov, (2001), "Understanding the toll of premature death among men in eastern Europe”, British Medical Journal, Vol. 323/7320, pp. 1051-1055.

Morrisson, C. and F. Murtin (2013), "The Kuznets Curve of Human Capital Inequality: 1870-2010." The Journal of Economic Inequality, Vol. 11/3, pp. 283-301.

Murdock, G.P. (1969), Ethnographic Atlas. 2nd print, University of Pittsburgh Press.

OECD (2013), How's Life? 2013: Measuring Well-being, OECD Publishing, Paris, http://dx.doi. org/10.1787/9789264201392-en.

Oxaal, Z. and S. Baden (1997), "Gender and empowerment: definitions, approaches and implications for policy”, BRIDGE, Report No. 40, www.bridge.ids.ac.uk/reports/re40c.pdf.

Paxton, P., J. Green, and M. Hughes, (2008), “Women in Parliament, 1945-2003: Cross-National Dataset" ICPSR ed. Ann Arbor, MI: Inter-university Consortium for Political and Social Research.

Przeworski, A. (2009), "Conquered or Granted? A History of Suffrage Extensions", British Journal of Political Science Vol. 39, pp. 291-321.

Rehm, J. et al. (2007), "Alcohol accounts for a high proportion of premature mortality in central and eastern Europe", The International Journal of Epidemiology, Vol. 36/2.

Rosenzweig, M.R. and T.P. Schultz. (1982), “Market Opportunities, Genetic Endowments, and Intrafamily Resource Distribution: Child Survival in Rural India”, The American Economic Review, Vol.72/4, pp. 803-15.

Salim, A. (2008) Challenging the Secular State: The Islamization of Law in Modern Indonesia, University of Hawai'i Press. 
Saxonberg, S. (2000), "Women in East European Parliaments", Journal of Democracy, Vol. 11/2, pp. 145-58.

Schmidt, A. and E. van Nederveen Meerkerk (2012), "Reconsidering The 'First male-Breadwinner Economy': Women's Labor Force Participation in the Netherlands, 1600-1900”, Feminist Economics, Vol. 18/4, pp. 69-96.

Schultz, T.P. (1988), "Education Investments and Returns", Handbook of Development Economics 1/1, pp. 543-630.

Sen, A. (1990), "Gender and Cooperative Conflicts", in Persistent Inequalities: Women and World Development, edited by I. Tinker, 123-149.

Sen, A. (1992), “Missing Women”, British Medical Journal Vol. 304, pp. 587-588.

Sen, A. (1999), Development as Freedom, Oxford University Press.

Sokoloff, K.L. and S.L. Engerman (2000), "History Lessons: Institutions, Factor Endowments, and Paths of Development in the New World", Journal of Economic Perspectives, Vol. 14/3, pp. 217-232.

Tertilt, M. (2005), “Polygyny, Fertility, and Savings”, Journal of Political Economy, Vol. 113/6, pp. 1341-1371.

United Nations (2013), The gender dimension of the Millennium Development Goals Report 2013, www. unwomen.org/en/news/stories/2013/7/the-gender-dimension-of-the-millennium-development-goalsreport-2013/\#sthash.DczDShxJ.dpuf.

University of California, Berkeley and Max Planck Institute for Demographic Research, Human Mortality Database, www.mortality.org.

Verba, S., N. Burns and K. Lehman Schlozman (1997), "Knowing and Caring about Politics: Gender and Political Engagement", The Journal of Politics, Vol. 59/4, pp. 1051-1073.

Waldron, I. (1967), "Why do women live longer than men?" Social Science and Medicine, Vol. 10/7-8.

Weldon, L. and M. Htun (2012), "Sex Equality in Family Law: Historical Legacies, Feminist Activism, and Religious Power in 70 Countries," https://openknowledge.worldbank.org/handle/10986/9204.

The World Bank, The Gender Equality as Smart Economics Project, http://go.worldbank.org/FSV68RJ1F0.

The World Bank (2011), World development report 2012: Gender equality and development. http://econ. worldbank.org/WBSITE/EXTERNAL/EXTDEC/EXTRESEARCH/EXTWDRS/EXTWDR2012/0,,contentMDK: 22999750 pagePK:64167689 piPK:64167673 theSitePK:7778063,00.html.

van Zanden, J.L. and T. De Moor (2009), "Girlpower: The European marriage pattern (EMP) and labour markets in the North Sea Region in the late medieval period", in The Long Road to Industrial Revolution, Brill. 